\title{
Enforcing the Custoinary International Law of Human Rights in Federal Court
}

In 1789 the framers of the First Judiciary Act granted to the newly created federal district courts original jurisdiction over civil actions "where an alien sues for a tort only in violation of the law of nations or a treaty of the Uinted States." 1 This jurisdictional grant, codified today at 28 U.S.C. $\S 1350^{2}$ and known as the Alien Tort Statute or the Alien Tort Claims Act, supported jurisdiction, in fact, only twice in nearly 200 years. ${ }^{3}$ Then, in 1980, in Filartiga v. Peña-Irala ${ }^{4}$ the Second Circuit Court of Appeals held that section 1350 granted jurisdiction over a tort claim brought by two Paraguayans against a former Paraguayan chief of police for the torture death of a inember of their family. The court found that customary international law grants all individuals certain fundamental human rights, including the right to be free froin official torture. Transgression of the custo1nary prohibition of official torture constituted a "violation of the law of nations" sufficient to trigger the jurisdictional grant of section $1350 . .^{5}$

Only four years later the Court of Appeals for the District of Columbia put in doubt the rule outlined by Filartiga. In Tel-Oren $v$. Libyan Arab Republic ${ }^{6}$ a panel of the court of appeals affirmed dismissal of a suit brought under section 1350 for alleged acts of terrorisin in Israel. Although unanimous in the decision to affirm disinissal, the panel divided sharply on the rationale. Judge Edwards agreed with the Filartiga holding that individuals may sue for violations of the law of nations, but found insufficient international consensus to indicate that

1. Act of Sept. 24,1789 , ch. $20, \S 9(\mathrm{~b}), 1$ Stat. 73,77 (codified as amended at 28 U.S.C. $\S 1350$ (1982)).

2. 28 U.S.C. $\$ 1350$ (1982). In its current codification the statute provides that " $[\mathrm{t}]$ he district courts shall have original jurisdiction of any civil action by an alien for a tort only, committed in violatiou of the law of nations or a treaty of the Umited States." Id. For purposes of simplicity this Comment will refer to the statute throughout as $\$ 1350$, although its codification at that section is relatively recent. See Act of Juue 25, 1948, ch. 646, $\S 1350,62$ Stat. 869, 934.

3. In Bolchos v. Darrel, 3 F. Cas. 810 (D.S.C. 1795) (No. 1607), the statute offered an alternative to admiralty jurisdiction; in Abdul-Rahman Omar Adra v. Clift, 195 F. Supp. 857 (D. Md. 1961), the court accepted jurisdiction under $\S 1350$. See infra notes 48-50, 59-64 and accompanying text.

4. 630 F.2d 876 (2d Cir. 1980).

5. Id. at 880 .

6. 726 F.2d 774 (D.C. Cir. 1984), cert. denied, 105 S. Ct. 1354 (1985). 
either terrorism or nonofficial torture violates the law of nations. ${ }^{7}$ Judge Bork suggested that separation of powers concerns mandate requiring individuals to demonstrate an express grant of a private cause of action before allowing them to mvoke section $1350 .^{8}$ Judge Robb, the third judge on the panel, stated that all human rights claims under section 1350 are nonjusticiable political questions. ${ }^{9}$

This Comment will examine three key issues presented by the TelOren reaction to Filartiga. First, it will consider whether section 1350 encompasses law of nations violations that have developed since enactment of the statute in 1789. Next, the Comment will examine the proposed requirement that plaintiffs sliow an express cause of action to invoke section 1350. Finally, it will assess objections, based on separation of powers principles as embodied in the act of state and political question doctrines, ${ }^{10}$ to the use of section 1350 as a basis for jurisdiction over aliens' liuman rights claims.

This Comment concludes that "violations of the law of nations" within the meaning of section 1350 must be construed to encompass those customary rules that have evolved since passage of the statute and that may evolve in the future. It concludes further that requiring an express grant of a private cause of action is unjustified $m$ higlt of what is known of the statute's origins, and is precluded by the nature of international law and the consequences for the statute. Indeed, this Comment suggests that allowing aliens to sue in Umited States courts for enforcement of certain fundamental human rights would serve important policy goals. Finally, this Comment argues that objections raised under the act of state and pohtical question doctrines do not pose serious obstacles to the proposed interpretation of the statute.

Part I of this Comment sets forth the relevant legal background. It delineates the fluctuating role of the individual during the development of the law of nations from the eigliteentli century, through the classical statist formulation of the nineteenth and early twentieth centuries, to the post-World War II emergence of an international law of human rights. Part I then describes the origins of section 1350 and its use before Filartiga. Part II presents the facts and holdings of Filartiga and TelOren, and describes the rationales articulated in eacli of the published opinions. Part III analyzes the three central issues noted above; its conclusions are summarized in the final section of this Comment.

7. Tel-Oren, 726 F.2d at 775-98 (Edwards, J., concurring). For a discussion of Judge Edwards's opinion, see infra notes $115-29$ and accompanying text.

8. Tel-Oren, 726 F.2d at 798-823 (Bork, J., concurring). For a discussion of Judge Bork's opinion, see infra notes $130-46$ and accompanying text.

9. Tel-Oren, 726 F.2d at 823-27 (Robb, J., concurring). For a discussion of Judge Robb's opinion, see infra notes $147-52$ and accompanying text.

10. See infra notes 131-32. 


\section{LEGAL BACKGROUND}

\section{A. The Development of the Law of Nations}

In 1789, when the Alien Tort Statute first gave federal district courts original jurisdiction over "all causes where an alien sues for a tort only in violation of the law of nations or a treaty of the United States,"11 the law of nations was part of the law of the United States. ${ }^{12}$ It was perceived of as a body of universal law conıprising rules to regulate niatters between individuals, between individuals and states, and between states. ${ }^{13}$ The law of nations extended to both civil and criminal injuries. ${ }^{14}$ Not only could the law of nations be violated by individuals, ${ }^{15}$ but

11. Act of Sept. 24, 1789, ch. 20, $\$ 9(\mathrm{~b}), 1$ Stat. 73,77 (codified as amended at 28 U.S.C. $\S 1350$ (1982)).

12. See Respublica v. De Longchamps, 1 Dall. 111 (Pa. 1784); 1 Op. Att'y Gen. 26, 29 (1792); Dickinson, The Law of Nations as Part of the National Law of the United States (pts. 1 \& 2), $101 \mathrm{U}$. PA. L. Rev. 26, 3435 (1952), 101 U. PA. L. REv. 792, 792-93 (1953). The year 1789, when the forerunner to $\S 1350$ was adopted, also witnessed the publication of a book by Jeremy Bentham, in which he coined the phrases "international jurisprudence" and "international law." See J. Bentham, AN INTRODUCTION TO THE PRINCIPLES OF MORALS AND LEGisLation 326 \& n.1, 328 n.1 (Hafner ed. 1948) (1st ed. London 1789). Professor D'Amato identifies the book's publication as the beginning of the movement toward a state-orientéd view of international law. See D'Amato, What Does Tel-Oren Tell Lawyers? Judge Bork's Concept of the Law of Nations Is Seriously Mistaken, 79 AM. J. INT'L L. 92, 102 \& n.27 (1985); see also infra note 17.

The accompanying summary of the developinent of the law of nations and international law is necessarily cursory. For a more comprehensive summary of the emergence of the international law of human rights, see Blum \& Steinhardt, Federal Jurisdiction over International Human Rights Claims: The Alien Tort Claims Act after Filartiga v. Peña-Irala, 22 HARV. INT'L L.J. 53, 6475 (1981); see also Note, Limiting the Scope of Federal Jurisdiction Under the Alien Tort Statute, 24 VA. J. INT'L L. 941, 943-45 (1984).

13. Dickinson writes:

It is to be emphasized ... that the Law of Nations in the eighteenth century embraced a good deal more than the body of practice and agreennent which came later to be called public international law. In the De Jure Belli ac Pacis of Hugo Grotius and in the treatises of his successors, it had been expounded as a universal law binding upon all mankind. ... The uriversal law was law for individuals no less than for states. As such, it was concerned somewhat indiscriminately with matters between individuals, between individuals and states, and between states.

Dickinson, supra note 12, at 26-27 (footnote omitted); see also D'Amato, supra note 12, at 103-04 (law of nations not confined to sovereign states alone).

14. See Dickinson, supra note 12 , at 29-32.

15. See, e.g., Respublica v. De Longchamps, 1 Dall. 111 (Pa. 1784) (defendant's assault on French consul-general violated law of nations); 1 Op. Att'y Gen. 26, 28 (1792) (discussing whether officer's entry into public minister's house to arrest minister's domestic was punishable under law of nations); see also Dickinson, supra note 12, at 792 ("the idea of individual offences against the Law of Nations was firmly established in countries of the common law in the eighteenth century").

In his sketch on the national judicial powers, Thomas Sergeant reported early efforts by Congress to ensure enforcement of the law of nations in state courts. Sergeant, $A$ Brief Sketch of the National Judiciary Powers Exercised in the United States, From the First Settlement of the Colonies to the Time of the Adoption of the Present Federal Constitution, reprinted in P. DU PONCEAU, A Dissertation on THE NATURE AND ExTENT OF THE JURisdiction of THE Courts of THE UNITED STATES 135-67 (Philadelphia 1824 \& photo. reprint 1972). These efforts included a 1781 
it could evidently be sued upon and enforced by individuals. ${ }^{16}$

In the nineteenth century, the countervailing concept of a state-oriented international law ${ }^{17}$ grew and flowered into its classical statist forinulation by $1900 .{ }^{18}$ The hallmarks of this classical systen of international law were twofold: the absolute equality and independence of sovereign states, and the exclusion of non-state actors from the international legal arena. ${ }^{19}$ Individuals thus assuined a inuch-diminished

recommendation to the states' legislatures to enact laws punishing various law of nations infractions affecting the national interest. Congress also recommended that the states "erect a tribunal, or ... . vest one already existing with power, to decide on offences against the law of nations, and ... authorize suits for damages by the party injured." Id. at 154. These actions, however, were not necessary for the enforcement of the law of nations in state courts, as the case of Respublica v. De Longchamps, 1 Dall. 111 ( $\mathrm{Pa}$. 1784), deinonstrated. Sergeant noted that a coinunittee of the states approved De Longchamp's conviction for violating the law of nations by insulting the secretary of the French legation, even though Pennsylvania had enacted no such law as Congress had recommended. Sergeant, supra, at 155.

16. Cf. 1 Op. Att'y Gen. 57, 58-59 (1795) (British company or individuals could bring civil suit for acts of hostility agamst British settlement in violation of law of nations), discussed infra at notes 51-53 and accoinpanying text ; D'Amato, supra note 12, at 104 (the law of nations applied to individuals as well as pohtical, quasi-pohtical, and nonpohtical entities so that a writer of 1789 "would have boggled at the attenpt to define the law of nations in terms of its subjects and objects"); Sergeant, supra note 15 , at 154 (congressional proposal concerning tort suits of parties injured by offenses agamst the law of nations).

17. During this period the phrase "the law of nations" continued as a synonym for "international law," but the law of nations now excluded individuals as legally competent parties. Cf. J. BRIERLY, THE LAW OF NATIONS 1 (H. Waldock 6th ed. 1963) ("The Law of Nations, or International Law, inay be defined as the body of rules and principles of action which are binding upon civilized states in their relations with one another."); 1 J. KENT, COMMENTARIES ON AMERICAN LAW 1 (1st ed. 1826) (law of nations defined as "that code of public instruction, which defines the rights and prescribes the duties of nations, in their intercourse with each other"). See infra note 19. For purposes of discussing 28 U.S.C. $\$ 1350$, this Comment uses the terms "the law of nations" and "international law" interchangeably, but with sensitivity to the evolved meaning of the forner, which originally contemplated individual enforcement in appropriate circumstances.

18. See Blum \& Steinhardt, supra note 12, at 64-65.

Both the law of nations and international law derive from two major sources, treaty and custoin. Treaties can theinselves create rights which are judicially enforceable without any further need for inplementing legislation. Treaties that do so are called "self-executing." See infra notes $194 \& 218$. Similarly, customary international law, those rules that have evolved as the "custom" of states, may recognize judicially cognizable rights and duties. Non-self-executing treaties, those that do not themselves purport to create rights and obligations, may be relevant as evidence of international custom. Thus, for instance, provisions of the Helsinki Accords concerning marriages between citizens of different states, although held to be non-self-executing, see Frolova v. USSR, 761 F.2d 370 (7th Cir. 1985), may still attest to growing consensus in the international community that citizens of different states have a right to marry without state interference. See also infra note 24.

19. Blum \& Steinhardt, supra note 12, at 64 . One scholar, writing in 1905 , articulated the classical statist formulation thus:

Since the Law of Nations is based on the coinmon consent of individual States, States are the principal subjects of International Law. This means that the Law of Nations is primarily a law for the international conduct of States, and not of their citizens. As a rule, the subjects of the rights and duties arising froin the Law of Nations are States solely and exclusively.

1 L. OPPENHEIM, INTERNATIONAL LAW 19 (H. Lauterpacht 8th ed. 1955); see also Note, supra note 12 , at 943. 
stature in this international law, with no legal capacity to enforce their rights. Considered only objects of international law, ${ }^{20}$ they could vindicate claims only vicariously through the sovereign states of which they were citizens. ${ }^{21}$ The inevitable result of this statist view of international law was to make what a state did to its own citizens entirely its own concern. A sovereign state did not have to answer to the international legal order for its treatment of its own citizens. ${ }^{22}$

The recognition of an international law of human rights in the afterinath of World War II wrought a fundamental change in the status of the individual. ${ }^{23}$ The United Nations Charter prescribed the specific goal of promoting "uriversal respect for, and observance of, human rights and fundamental freedonss for all without distinction as to race, sex, language, or rehgion."24 Subsequently, the Universal Declaration of

20. See generally Manner, The Object Theory of the Individual in International Law, 46 AM. J. INT'L L. 428 (1952).

21. See generally W. Friedmann, O. Lissitzyn \& R. Pugh, Cases and Materiais on International LAW 745-879 (1969); M. MCDougal, H. LASSWEll \& L.C. Chen, HumaN Rights AND World Public ORder 747 n.39 (1980); L. SOHN \& T. Buergenthal, INTERNATIONAL PRotection OF HuMAN Rights 23-136 (1973).

22. See Salimoff \& Co. v. Standard Oil Co., 262 N.Y. 220, 186 N.E. 679 (1933) (Russia's confiscation and sale of its nationals' oil not a legal violation of law of nations); J. BRIERLY, supra note 17, at 291-96; Blum \& Steinhardt, supra note 12, at 65; $c f$. D'Amato, supra note 12, at 104 ("In the mid-1930s, when Stalm supervised the genocide of ten million Russian kulaks, the world took little notice; under positivist theory, what a nation did to its own citizens did not amount to a breach of "international law." ").

23. See H. Lauterpacht, International Law aNd HumaN Rights 4 (1968) ("[T]he individual has acquired a status and a stature which have transformed him from an object of international coinpassion into a subject of international right."); Blum \& Steinhardt, supra note 12, at 64-67. This reversal, under human rights law, of the classical ("positivist") statist trend is for D'Amato a "return to the pre-19th century conception of 'the law of nations.' " D'Amato, supra note 12 , at 104 .

For purposes of ascertaining the law of nations, the Statute of the International Court of Justice, which establishes the Court and defines its jurisdiction, is instructive. It provides that the Court shall apply:

(a) international conventions, whether general or particular, establishing rules

expressly recognized by the contesting states;

(b) international custom, as evidence of a general practice accepted as law;

(c) the general primciples of law recognized by civilized nations;

(d) ... judicial decisions and the teachings of the most highly qualified publicists of

the various nations, as subsidiary means for the determination of rules of law.

Statute of the International Court of Justice art. 38, appended to U.N. CHARTER; see also J. BRIERLY, supra note 17, at 56-68. This approach largely duphicates that established by the United States Supreme Court more than eighty years ago in The Paquete Habana, 175 U.S. 677 (1900), quoted infra at note 98 .

24. U.N. Charter art. 55. Article 56 of the U.N. Charter provides, "All Members pledge themselves to take joint and separate action in cooperation with the Organization for the achievement of the purposes set forth in Article 55." Commentators have long debated whether articles 55 and 56 create legally binding obligations on U.N. meinber states. Compare H. KELSEN, THE LAW OF THE UNITED NATIONS, 99-100 (1950) (pledge not a "true obligation") with Schachter, The Charter and the Constitution: The Human Rights Provisions in American Law, 4 VAND. L. REV. 643, 653 (1951) (pledge creates legal obligation) and Schwelb, The International Court of Justice and the Human Rights Clauses of the Charter, 66 AM. J. INT'L L. 337, 350 (1972) (International Court of 
Human Rights, ${ }^{25}$ the International Covenant on Economic, Social and Cultural Rights, ${ }^{26}$ and the International Covenant on Civil and Political Rights ${ }^{27}$ further clarified the scope and definition of human rights. The process is ongoing. ${ }^{28}$ Most significantly, the "expressed will of governments" 29 to recognize a core of truly international human rights ${ }^{30}$ has "supercede[d] the fundamentally statist principle that governments have no hability under the law of nations for wrongful conduct which affects their own nationals." ${ }^{31}$ To the extent that individuals are now recognized as possessing substantive international human rights vis-á-vis states, they have legal capacity under international law. ${ }^{32}$

\section{B. Construction of Section 1350 Before Filartiga}

The pre-Filartiga sources construing section 1350 are few. The legislative history is meager. ${ }^{33}$ The legislative history that can be determined suggests that the statute was imtended to avoid local bias in aliens' suits and to obtain uniform judicial interpretation and application of the

Justice interpretation shows obligations binding). Whether or not articles 55 and 56 are legally binding as treaty provisions, they are relevant to ascertaining the existence of international consensus regarding the protection of human rights.

25. G.A. Res. 217A, U.N. Doc. A/810, at 71 (1948) [hereinafter cited as UDHR]. The UDHR is now widely regarded as the authoritative interpretation of the U.N. Charter. It provides a catalogue of those human rights deeined fundamental by the international coininunity. See Lillich, The Role of Domestic Courts in Enforcing International Human Rights Law, in GU1DE To INTERNATIONAL HUMAN Rights Practice 223, 227 (H. Hannum ed. 1984).

The UDHR articulates numerous human rights, ranging from mandatory rights such as freedion from torture, UDHR, supra, art. 5, at 73, and arbitrary arrest, id. art. 9, at 73, to the more hortatory, such as the right to social security, id. art. 25 , at 76 . Not all of these rights would qualify for enforcement in actions based on $\$ 1350$. Very few possess the requisite degree of consensus, specificity of definition, and obligatory nature to be judicially cognizable "international torts." See infra notes 211-22 and accoinpanying text.

26. G.A. Res. 2200, 21 U.N. GAOR Supp. (No. 16) at 49, U.N. Doc. A/6316 (1966).

27. Id. at 52 .

28. For a comprehensive list of human rights treaties, agreeinents and declarations, with United States case annotations, see INTERNATIONAL HUMAN RIGHTS INSTRUMENTS (R. Lillich ed. 1985).

29. See Bluin \& Steinhardt, supra note 12 , at 66 .

30. The Uiniversal Declaration of Human Rights provides that "[e]veryone is entitled to all the rights and freedorns set forth in this Declaration, without distinction of any kind, such as race, colour, sex, language, religion, political or other opinion, national or social origin, property, birth or other status." UDHR, supra note 25 , art. 2, at 72.

31. Bluin \& Steinhardt, supra note 12, at 67; see also D'Aunato, supra note 12, at 104.

32. Section 1350 grants jurisdiction over tort actions based on violations of either the law of natious or Uinited States treaties. The latter category of course encompasses self-executing treaties to which the United States is a party. The jurisdictional inquiry under this branch of $\S 1350$ is thus controlled by the language of the particular treaty and its legislative history. This Comment limits its discussion to $\S 1350$ actions based on the customary international law of human rights.

33. Section 1350's obscure history prompted Judge Friendly to remark that "[t]his old but little used section is a kind of legal Lolengrin; although it has been with us since the first Judiciary Act, $\S 9,1$ Stat. 73, 77 (1789), no one seeins to know whence it came." IIT v. Vencap, Ltd., 519 F.2d 1001, 1015 (2d Cir. 1975). 
law in cases implicating international concerns. ${ }^{34}$ Early cases and autliorities supporting application of the statute liad little difficulty in inferring a private right of action under international law; ${ }^{35}$ lowever, the statute was rarely invoked prior to $1980 ; ;^{36}$ and only twice did it successfully support federal subject matter jurisdiction. ${ }^{37}$ Moreover, the more recent pre-Filartiga cases, apparently influenced by the statist model of international law, have indicated that section 1350 does not provide jurisdiction over claims by aliens against states of which they are citizens. ${ }^{38}$ None of the cases construing the statute actually involved a claim under the international law of human riglits. Nonetheless, these autliorities shed light on Filartiga and Tel-Oren.

\section{Legislative History of Section $\mathbf{1 3 5 0}$}

The limited legislative history does not indicate Congress's precise purpose in enacting section 1350, but that purpose may be derived from the overarching design of the federal judiciary, of which the statute is a part. The framers of the First Judiciary Act sought to place questions of national import, such as tliose involving the law of nations or treaties, within the liands of the federal judiciary. ${ }^{39}$ The rationale underlying section 1350 was mucli the same as that underlying the Act's grant of diversity jurisdiction in cases involving citizens of different states. The grant of federal jurisdiction over cases imvolving diversity of citizenship or allegiance was intended to serve two purposes: (1) to assure aliens or diverse citizens that local bias would play no part in the adjudication of their claims; and (2) to ensure uniform judicial interpretation and application of laws regarding matters of parainount national concern. ${ }^{40}$ Witl ahen plaintiffs, it was especially important to provide for fair and uniform adjudication; a denial of justice ${ }^{41} \mathrm{~m}$ the nation's courts could create an

34. See infra text accompanying notes 39-43.

35. See infra text accompanying notes 48-58.

36. IIT v. Vencap, Ltd., 519 F.2d 1001, 1015 (2d Cir. 1975); see also 13B C. WRIGHT, A Miller \& E. Cooper, Federal Practice and Procedure: Jurisdiction $§ 3585$, at 329 \& n.11 (2d ed. 1984) (statute relied on rarely).

37. Abdul-Rahman Omar Adra v. Clift, 195 F. Supp. 857 (D. Md. 1961); Bolchos v. Darrel, 3 F. Cas. 810 (D.S.C. 1795) (No. 1607). For a discussion of these cases, see infra notes 48-50, 59-64 and accompanying text.

38. See infra text accompanying notes 66-82.

39. See generally Dickinson, supra note 12, at 34-55 (concerted attempt to place questions regarding law of nations and treaties under control of federal courts). Dickinson observes: "In brief, and in general, the implementing of national judicial power in matters of international concern is today in the pattern first detailed in $1789 \ldots$... Id. at 55 .

40. See Dickinson, supra note 12 , at 796.

41. A "denial of justice" may be characterized as "an mjury involving the responsibility of the state committed by a court of justice." J. BRIERLY, supra note 17, at 286. Brierly hists, in addition to denying foreigners access to the courts altogether, "corruption, threats, unwarrantable delay, flagrant abuse of judicial procedure, [or] a judgment dictated by the executive, or so mainfestly unjust that no court which was both competent and honest could have given it" as other examples of 
mternational incident and even, at the extreme, cause a war. ${ }^{42}$

Although conflicting judicial expression may have seeined a serious danger to the framers of the First Judiciary Act, the statute did not altogether remove jurisdiction over alien tort claims from the states. Federal district courts received cognizance "concurrent with the courts of the several States, or the circuit courts, as the case may be."43 The potential for harm, however, was greatly reduced by the Supreme Court's holding in Banco Nacional de Cuba v. Sabbatino ${ }^{44}$ that the mterpretation of international law is a federal question. ${ }^{45}$ The Court cited section 1350 as an example of a statutory provision "reflectimg a concern for umformity in

denials of justice. Id. at 286-87. Other instances possibly to be included are acts or omissions of other government organs closely connected with the adninistration of justice, such as "execution without trial, inexcusable failure to bring a wrongdoer to trial, long imprisonment before trial, grossly madequate punishnient, or failure to enforce a judgment duly given." Id. at 287.

42. Mindful of this threat to the peace of the union, Alexander Hamilton argued emphatically for federal jurisdiction over cases implicating international issues:

The Union will undoubtedly be answerable to foreigu powers for the conduct of its nenibers. And the responsibility for an injury ought ever to be accompanied with the faculty of preventing it. As the denial or perversion of justice by the sentences of courts, as well as in any other nianner, is with reason classed among the just causes of war, it will follow that the federal judiciary ought to have cognizance of all causes in which the citizens of other countries are concerned. This is not less essential to the preservation of the public faith, than to the security of the public tranquility. A distinction nay perhaps be imagined between cases arising upon treaties and the laws of nations and those which may stand nierely on the footing of the nunicipal law. The former kind may be supposed proper for the federal jurisdiction, the latter for that of the States. But it is at least problematical, whether an unjust sentence against a foreiguer, where the subject of controversy was wholly relative to the lex loci, would not, if unredressed, be an aggression upon his sovereign, as well as one which violated the stipulations of a treaty or the general law of nations. And a still greater objection to the distinction would result from the immense difficulty, if not impossibility, of a practical discrinination between the cases of one complexion and those of the other. So great a proportion of the cases in which foreigners are parties, involve national questions, that it is by far most safe and nost expedient to refer all those in which they are concerned to the national tribunals.

The Federalist, No. 80, at 341-42 (A. Hanilton) (C. Beard ed. 1959).

43. Act of Sept. 24,1789 , ch. $20, \S 9,1$ Stat. 73,77 (codified as amended at 28 U.S.C. $\S 1350$ (1982)); see Dickinson, supra note 12, at 47. State common law courts could hear aliens' tort suits under the doctrine of transitory torts. This doctrime provides that a tort "follows" the tortfeasor wherever she may go, enabling a court with personal jurisdiction over her to adjudicate the claim under the law of the tort situs. See Blun \& Steinhardt, supra note 12, at 63. Because the law of nations was decmed, at least initially, part of state common law (as well as federal coninion law), see Respublica v. De Longchamps, 1 Dall. 111, 114 (Pa. 1784), state courts could entertain suits alleging violations of the law of nations.

Although the framers did not grant exclusive federal jurisdiction over suits involving the law of nations, "the broad outhines of an intended national jurisdiction with respect to foreigners were fairly clear." Dickinson, supra note 12, at 48 . The grant of concurrent jurisdiction may have been the result of political compromise. Id. at 47-48. Granting concurrent jurisdiction, however, would not necessarily underunine the framers' purpose of ensuring uniform interpretation and application of laws, since what was at stake was interpretation, by state or federal courts, of the same body of law. Whatever "patchwork effect" ensued would stem fron divergent interpretations and applications of the law of nations, not front adoption by different courts of divergent legal rules.

44. 376 U.S. 398 (1964). See infra text accompanying notes 250-58.

45. Id. at 425 . 
this country's dealings with foreign nations and indicating a desire to give matters of international significance to the jurisdiction of federal institutions."46 Thus, after Sabbatino, errant state court dispositions of international legal issues can be superceded by apphication of the federal common law to which they are subordinate.

\section{Authority Supporting Application of Section $\mathbf{1 3 5 0}$}

Section 1350's jurisdictional grant was little used for nearly 200 years, ${ }^{47}$ though its initial use occurred soon after passage of the First Judiciary Act. A dictum in Bolchos v. Darrel, ${ }^{48}$ decided in 1795, suggests that section 1350 could have provided jurisdiction in a case arising out of a prize capture. Bolchos, a French captain, had taken an enemy Spanish ship carrying slaves inortgaged to an Enghishman. Bolchos brought the prize to Charleston, where Darrel, agent of the Englishman, seized and sold the slaves. The court found that although Bolchos's seizure of neutral property from the Spanish ship normally would have violated the law of nations, in this case a French-American treaty specifically provided that all seized property would be forfeit. Judgment went to Bolchos. ${ }^{49}$ Before deciding on the merits, the court concluded that it had admiralty jurisdiction. In support of its decision, the court noted, first, that the appropriate state court had already disinissed the action as belonging in admiralty, and, second, that section 1350 would in any event support jurisdiction. ${ }^{50}$

46. Id. at 427 n.25.

47. This record of disuse may be attributable to the obscurity of $\S 1350$ 's purpose and application, see supra note 33 , and the difficulty of showing a violation of the law of nations, see infra note 97. Another reason for the dearth of $\S 1350$ cases-at least those against alien defendants, where diversity jurisdiction would be unavailable-may have been the difficulty of gaining personal jurisdiction over the defendant. In personam jurisdiction in $\S 1350$ cases in effect requires that plaintiff and defeudant be present in the court's territorial jurisdiction simultaneously. See Hassan, Panacea or Mirage? Domestic Enforcement of International Human Rights Law: Recent Cases, 4 Hous. J. INT'L L. 13, 17 (1981).

In the heyday of the regime embodied by Pennoyer v. Neff, 95 U.S. 714 (1878), personal jurisdiction would have required that an alien defendant be served within the forum territory. The modern "ininimum contacts" approach introduced by International Shoe Co. v. Washington, 326 U.S. 310 (1945), has not much eased the plaintiff's task. In the absence of a relevant federal statute or court order, service of process depends on the statutes and rules of the state in which the district court sits. See FED. R. CIV. P. 4(e). But even the broadest of state long-arm statutes must satisfy the due process requirements of International Shoe and its progeny. See, e.g., CAL. Crv. Proc. CODE $\$ 410.10$ (West 1973) (authorizing exercise of jurisdiction "on any basis not inconsistent with the Constitution of this state or of the United States"). Thus, unless the alien defendant has coinmitted the international tort within the forum territory, or has other contacts sufficient to support "general jurisdiction" over the unrelated tort claim, minimum contacts likely will be lacking. In personam jurisdiction then depends solely on the defendant's physical presence in the forum territory.

48. 3 F. Cas. 810 (D.S.C. 1795) (No. 1607).

49. Id. at 811 .

50. Id. at 810 . 
More enlightening is an opinion which Attorney General William Bradford issued that same year. ${ }^{51}$ American traders abroad had aided French privateers im plundering a British settlement on the coast of Africa. The Attorney General stated that these acts constituted a breach of neutrality im violation of a treaty with England and would be indictable as offenses against the Uirited States "so far as they were committed within the territory or jurisdiction thereof." 52 If the traders had committed the crimes on the high seas and the treaty's terins had not dictated otherwise, the offenses could have been prosecuted in any district where the offenders might have been found. But, in the actual case, the foreign situs of the acts placed the American traders beyond the power of United States courts to prosecute and puinsh. Although criminal prosecution, therefore, was impossible, the Attorney General pointed out that the injured aliens could bring a civil suit under section $1350 .{ }^{53}$ Thus, the saine acts which might result in criminal sanctions under United States law could support a civil action under section 1350 as a violation of the law of nations.

More than a century later, Attorney General Charles Bonaparte indicated that section 1350 may provide alien plaintiffs both a "forum" and a "right of action" under the proper circumstances. ${ }^{54}$ Bonaparte issued this opinion in response to a dispute between the United States and Mexico over the Rio Grande boundary. The International Water Boundary Commission had nuade a specific finding that an American company had "wrongfully and knowingly cause[d] a change in the current channel of the Rio Grande." redressing the wrong, for the Commission was not empowered to adjudicate or enforce clainis of title to land, dainage to property, or control of riparian rights. The Attorney General suggested that "existing statutes provide a right of action and a forum." 56 He cited section 1350 and the predecessor of 28 U.S.C. $\S 1332$ (diversity jurisdiction). ${ }^{57}$ The language of the opinion, however, is anibiguous. It is unclear whether the Attorney General meant to suggest that either jurisdictional grant provided both forum and cause of action, or that one provided only a forum and

51. 1 Op. Att'y Gen. 57 (1795).

52. Id. at 58.

53. The Attorney General stated:

[T] here can be no doubt that the company or individuals who have been injured by these acts of hostility have a remedy by a civil suit in the courts of the United States; jurisdiction being expressly given to these courts in all cases where an alien sues for a tort only, in violation of the laws of nations, or a treaty of the United States. ...

Id. at 59 (emphasis in original).

54. 26 Op. Att'y Gen. 250 (1907).

55. Id. at 251.

56. Id. at 252 .

57. Id. at $252-53$. 
the other provided a cause of action. ${ }^{58}$

Not until 1961 did a court explicitly rest federal subject matter jurisdiction on section 1350. The case, Abdul-Rahman Omar Adra v. Clift, ${ }^{59}$ imvolved a claim for equitable relief, the return of a child to rightful custody. The alien plaimtiff, a Lebanese national, sued his former wife, an Iraqi national, and her American husband for custody of plaintiff's daughter under Lebanese and Moslem law. Personal jurisdiction proved no obstacle once the plaintiff located his ex-wife and her American husband in Baltimore, where he effected personal service. He alleged that after he had become entitled to custody, his ex-wife had taken the child from country to country under an Iraqi passport, concealing the daughter's naine and nationality. ${ }^{60}$ Althougli the court ultimately rejected plaintiff's prayer for rehef in the best interests of the child, it assumed jurisdiction under 28 U.S.C. $\$ 1350$. The court applied a two-step analysis. It determined, first, that plaintiff had alleged a tort: the "unlawful taking or withholding of a minor child from the custody of the parent or parents entitled to such custody."61 Next, it concluded tliat defendants liad committed this tort in violation of the law of nations by falsely obtaining an Iraqi passport for the child. ${ }^{62}$ In the course of this analysis the court rejected defendant's argument that the law of nations does not address the conduct of individuals. ${ }^{63}$ Moreover, the court determined

58. In Tel-Oren, Judge Edwards cited the Attorney General's opinion as authority for the proposition that $\$ 1350$ provides both forum and right of action. See Tel-Oren v. Libyan Arab Republic, 726 F.2đ 774, 780 (D.C. Cir. 1984) (Edwards, J., concurring), cert. denied, 105 S. Ct. 1354 (1985). Even if Judge Edwards is correct in the view that the two statutes provided alternative bases for civil actions, his reading of Bonaparte's opinion may be overly expansive. It is still possible that the Attorney General viewed $\S 1350$ as providing jurisdiction alone. Bonaparte indicated that the success of the action "would depend upon whether the diversion of the water was an injury to substantial rights of citizens of Mexico under the principles of international law or by treaty, and could only be deterinined by judicial decision." 26 Op. Att'y Gen. 250, 253 (1907). Bonaparte thus seems to concede that the success of the action depends upon the international law (or U.S. treaty) right claimed by the alien plaintiff. In that case it would be inore accurate to say that international law, or a U.S. treaty, provides the cause of action. See discussion infra at notes 190-201 and accompanying text.

59. 195 F. Supp. 857 (D. Md. 1961).

60. Id. at $859-61$.

61. Id. at $862-63$.

62. Id. at $864-65$.

63. The court stated: "Defendants argue that international law is divided into two inutually exclusive branches, the law of nations and private international law. [The case] relied on by defendants does not so hold; there is some intertwining of the branches." Id. at 864. The court went on to explain that certain "internationally illegal" acts may subject an individual to punishment even by a country not his own and even though the acts are consuminated beyond that country's territory and have no connection with it. Thus " " $t]$ he injunctions of international law that may be applicable to the private individual do not necessarily disappear when he enters the territory of his own or of any other State. He learns that there are acts of which that law there itself forbids the coinunission by any one whomsoever." "Id. (quoting $1 \mathrm{C}$. HYDE, INTERNATIONAL LAw $\S 11 \mathrm{~A}$, at 34 (2d rev. ed. 1945)). 
that abstention from jurisdiction was particularly inappropriate in this case. Congress had given federal courts jurisdiction over claims of precisely this nature, those brought by atiens and implicating foreign relations. $^{64}$

\section{Cases Dismissing Section 1350 Jurisdiction}

Courts declining jurisdiction under section 1350 have generally done so because of plaintiff's failure to demonstrate that a rule of international law has been violated. ${ }^{65}$ The courts' understanding of the individual's status under international law has colored, and occasionally controlled, their inquiries into what constitutes a violation of the law of nations. Two such cases, Lopes v. Reederei Richard Schroder ${ }^{66}$ and Dreyfus $v$. Von Finck, ${ }^{67}$ merit discussion because they illustrate principles rehed on in Filartiga and Tel-Oren.

Lopes involved a claim of unseaworthiness and negligence. Plaintiff, an alien longshoreman domiciled in Permsylvania, sued defendant shipowner, also an alien. Plaintiff based jurisdiction on section 1350. The claim of unseaworthiness posed the court little difficulty. It concluded that the doctrine was a judicial creation unique to the United States and did not originate from the law of nations or any treaty. ${ }^{68}$ The analysis of negligence was more involved. Stressing that examination of the phrase "law of nations" must take into account the organic development of the term, ${ }^{69}$ the court proceeded to consider the various sources of the law of

64. The court pointed out that:

Plaintiff is a citizen of a friendly nation, with which the United States has long had cultural contacts. An alien, understandably though unjustifiably, may prefer to bring an action for a tort in a federal court rather than in a local court, and Congress has authorized him to do so in this limited class of cases. The importance of foreign relations to our country today cautions federal courts to give weight to such considerations and not to decline jurisdiction given by an Act of Congress unless required to do so by dominant considerations. Adra, 195 F. Supp. at 865.

65. See, e.g., Huynh Thi Anh v. Levi, 586 F.2d 625, 629 (6th Cir. 1978) (grant of child custody to grandparents over foster pareuts not a rule of international law); Benjainins v. British European Airways, 572 F.2d 913, 916 (2d Cir. 1978) (law of nations does not prohibit air crashes), cert. denied, 439 U.S. 1114 (1979); IIT v. Vencap, Ltd., 519 F.2d 1001, 1015 (2d Cir. 1975) (Eighth Commandment, "Thou shalt not steal," not part of law of nations); Abiodun v. Martin Oil Serv., 475 F.2d 142, 145 (7th Cir.), cert. denied, 414 U.S. 866 (1973) (fraudulent failure to train plaintiffs as executives not a violation of international law); Khedivial Line, S.A.E. v. Seafarers' Int'I Union, 278 F.2d 49, 52 (2d Cir. 1960) (no injunction against picketing by U.S. seamen since law of nations does not give universal right of unimpeded access to harbors); Jafari v. Islamic Republic of Iran, 539 F. Supp. 209, 215 (N.D. Ill. 1982) (government's expropriation of property of its own nationals not prohibited by law of nations); Valanga v. Metropolitan Life Ins. Co., 259 F. Supp. 324, 327-29 (E.D. Pa. 1966) (claim for proceeds from life insurance policy did not allege tort in violation of law of nations or U.S. treaty).

66. 225 F. Supp. 292 (E.D. Pa. 1963).

67. 534 F.2d 24 (2d Cir.), cert. denied, 429 U.S. 835 (1976).

68. Lopes, 225 F. Supp. at 295.

69. Id. at 295-96 (citing Romero v. International Terminal Operating Co., 358 U.S. 354, 360 
nations set forth in United States v. Smith. ${ }^{70}$ The sources listed were the works of jurists, the general usage and practice of nations, and judicial decisions recognizing or enforcing that law. ${ }^{71}$ An examination of these sources convinced the court that neither in 1789 nor in succeeding years was neghigence custonnarily treated as a violation of the law of nations.

From its review of the authorities the court sought to derive a general test for determining whether conduct violates the law of nations under section 1350. It concluded that:

the phrase "in violation of the law of nations," for the purpose of deciding this issue, ineans, inter alia, at least a violation by one or more individals of those standards, rules or customs (a) affecting the relationship between states or between an individual and a foreign state, and (b) used by those states for their common good and/or in dealings inter se..$^{72}$

The court thus implied that the law of nations is not concerned with a state's treatment of its own citizens. ${ }^{73}$

In Dreyfus v. Von Finck ${ }^{74}$ a Swiss citizen and resident sought recovery from West German citizens and residents for the alleged confiscation of property in Nazi Germany in 1938. Commencing the action in the Southern District of New York by attaching defendants' assets there, plaintiff claimed jurisdiction under 28 U.S.C. $\S 1350$ and 28 U.S.C. $\S 1331$ (general federal question provision) ${ }^{75} \mathrm{He}$ alleged that defendants had "taken" his interest in a banking firm when he sold it under duress

(1959), where the Supreme Court explained that "proper construction" of 28 U.S.C. \$ 1331 must take into account the evolutionary process by which the statute has developed from its origins in Article III and the First Judiciary Act).

70. 18 U.S. (5 Wheat.) 153 (1820). Smith imvolved a claim that a federal statute proscribing "the crime of piracy [on the high seas] as defined by the law of nations," Act of Mar. 3, 1819, ch. 77, $\S 5$, 3 Stat. 510, 513-14, was unconstitutionally vague. After examining the relevant sources of international law, the Court found a conseusus that rendered the crime "sufficiently and constitutionally defined" to afford a basis for the death sentence. Smith, 18 U.S. (5 Wheat.) at 162.

71. Id. at $160-61$.

72. Lopes, 225 F. Supp. at 297 (emphasis added). Although it acknowledged the Adra decision, see $i d$. at $296 \mathrm{n} .18$, the Lopes court did not discuss Adra's two-step approach to the construction of $\S 1350$. It preferred instead to apply the rule quoted in the text. This passage from Lopes was adopted by the Second Circuit in IIT v. Vencap, Ltd., 519 F.2d 1001, 1015 (2d Cir. 1975), and viewed by the district court in Filartiga as binding precedent. See infra note 88 and accompanying text.

73. Since plaintiff had failed to meet the statute's jurisdictional requirements, the court considered the possibility of diversity jurisdiction under 28 U.S.C. $\$ 1332$. Lopes, 225 F. Supp. at 297. The court found that the parties were not diverse for purposes of that statute; both sides included alien parties. See 1 J. MOORE, J. LuCAS, H. FinK, D. WECKSTEIN \& J. WiCKer, MOORE'S FEDERAL Practice $\{0.75[1 .-2]$, at 709.6-709.7 (2d ed. 1985). The court ruled that it would dismiss the complaint unless plaintiff refiled in admiralty. Lopes, 225 F. Supp. at 297.

74. 534 F.2d 24 (2d Cir.), cert. denied, 429 U.S. 835 (1976).

75. Section 1331 gives district courts "original jurisdiction of all civil actions arisiug under the Constitution, laws, or treaties of the United States." 28 U.S.C. $\S 1331$ (1982). Significantly, Congress did not grant general federal question jurisdiction to district courts until 1875. See Act of Mar. 3, 1875, ch. 137, $\S 1,18$ Stat. 470 . The relationship between $\S 1350$ and $\S 1331$ in the context of human rights claims is discussed infra at note 210 . 
for a grossly low price after being forced to emigrate. Further, defendants allegedly had repudiated a 1948 settlement agreement. This conduct, plaintiff asserted, violated four United States treaties or pacts. ${ }^{76}$

The court of appeals affirmed the trial court's dismissal of the claim. It held, first, that although sections 1331 and 1350 do not "create a cause of action" for a plaintiff seeking recovery under a treaty, they empower the district court "to determine whether . . . a cause of action exists."77 Next, however, it found that none of the treaties provided plamtiff a "private right of action."78 Although general treaties can confer upon citizens legally enforceable rights, the court stated, as a rule they do not do so. Treaties will rarely provide a sufficiently direct connection with a private claim to support the "arismg under" jurisdiction of section 1331. The court explained that "[i]t is only when a treaty is self-executing, when it prescribes rules by which private rights may be determined, that it may be rehed upon for the enforcement of such rights."79 Because the four treaties im question contamed no provisions dealing with expropriation by Germans of German nationals' property, and conferred no private rights regarding such property which were enforceable im American courts, the court found dismissal proper.

These grounds were sufficient to decide the case, but the court went on in dicta to address the first prong of section 1350, that concerning the law of nations. Characterizing the law of nations as statist in orientation, ${ }^{80}$ the court set forth two propositions regarding that body of law. First, it suggested that its treaty analysis was equally valid for the first prong of the statute, since "[1]ike a general treaty, the law of nations has been held not to be self-executing so as to vest a plaintiff with individual legal rights." "violations of imternational law do not occur when the aggrieved parties are nationals of the acting state."

76. The treaties allegedly violated were the Four Power Occupation Agreement, Nov. 14, 1944, 5 U.S.T. 2062, T.I.A.S. No. 3070, 236 U.N.T.S. 359 ("Agreement on Control Machinery in Germany"); the Kellogg-Briand Peace Pact, Aug. 27, 1928, 46 Stat. 2343, T.S. No. 796, 94 L.N.T.S. 57; the Treaty of Versailles, June 28, 1919, 225 C.T.S. 188 (submitted to Congress but not ratified); the Hague Convention No. IV, Oct. 18, 1907, 36 Stat. 2277, T.S. No. 539, 205 C.T.S. 277.

77. Dreyfus, 534 F.2d at 28.

78. Id. at 30 .

79. Id.

80. The court reported that "[t] here is a general consensus ... that [the law of nations] deals primarily with the relationship among nations rather than among individuals." Id. at 30-31. The court further stated that the law of nations "governs civilized states in their dealings with each other." Id. at 31.

81. Id. at 31 (citing Pauling v. McElroy, 164 F. Supp. 390, 393 (D.D.C. 1958), affd., 278 F.2d 252 (D.C. Cir.), cert. denied, 364 U.S. 835 (1960)).

82. Dreyfus, 534 F.2d at 31 . The Dreyfus court did not discuss $A d r a$ in interpreting the $\S 1350$ phrase, "violation of the law of nations." 
Thus, the courts in both Lopes and Dreyfus adopted a statist conception of international law in construing section 1350.

\section{II}

\section{THE FILARTIGA AND TEL-OREN OPINIONS}

\section{A. Filartiga v. Peña-Irala}

In Filartiga v. Peña-Irala ${ }^{83}$ the Second Circuit Court of Appeals rejected the statist inodel of international law. A unanimous court held that "international law confers fundamental rights upon all people vis-avis their own governments," 84 and that section 1350 grants jurisdiction over claims that those rights have been violated. ${ }^{85}$

In Filartiga, Dr. Joel Filartiga and his daughter Dolly, both Paraguayan nationals, sued a third Paraguayan national in U.S. district court for the alleged death by torture of a family inember. According to the coinplaint, in 1976 the defendant Peña-Irala, then chief of police in Asunción, Paraguay, kidnaped Dr. Filartiga's seventeen-year-old son and tortured him to death. That saine day police took the victim's sister to the defendant's hoine to show her the corpse, which displayed sigus of severe torture. The killing was allegedly in retaliation for Dr. Filartiga's longstanding opposition to President Alfredo Stroessner's regime. Dr. Filartiga instituted a criminal action in Paraguay against Peña-Irala and the police, which was still pending four years later when the Filartigas' appeal reached the Second Circuit. That action allegedly resulted in the

83. 630 F.2d 876 (2d Cir. 1980). Filartiga is already the subject of a great deal of hiterature, but is discussed here in hight of its seminal role in the interpretation of $\S 1350$ claims arising from human rights violations. Other discussions of Filartiga imclude Bilder, Integrating International Human Rights Law into Domestic Law-U.S. Experience, 4 Hous. J. INT'L L. 1 (1981); Blum \& Steinhardt, supra note 12; D'Zurilla, Individual Responsibility for Torture Under International Law, 56 TUL. L. REv. 186 (1981); Hassan, supra note 47; Oliver, Problems of Cognition and Interpretation in Applying Norms of Customary International Law of Human Rights in United States Courts, 4 Hous. J. INT'L L. 59 (1981) [heremafter cited as Oliver, Problems of Cognition]; Paust, Litigating Human Rights: A Commentary on the Comments, 4 Hous. J. INT'L L. 81 (1981); Schneebaum, International Law as Guarantor of Judicially-Enforceable Rights: A Reply to Professor Oliver, 4 Hous. J. INT'L L. 65 (1981) [hereinafter cited as Schneebaum, International Law as Guarantor]; Case Comment, Torture As a Violation of the Law of Nations: Interpreting the Alien Tort StatuteFilartiga v. Peña-Irala, 7 BrookLyN J. INT'L L. 413 (1981); Case Comment, The Alien Tort Statute: Implications of Filartiga v. Pena-Irala, 15 GA. L. REv. 504 (1981); Case Comment, 28 U.S.C. 1350: A Legal Remedy for Torture in Paraguay?, 69 GEo. L.J. 833 (1981); Case Comment, International Law and Human Rights-Alien Tort Claims Under 28 U.S.C. $\$$ 1350: Filartiga v. Pena-Irala, 66 MinN. L. REv. 357 (1982); Case Comment, Torture as a Tort in Violation of International Law: Filartiga v. Peña-Irala, 33 STAN. L. REv. 353 (1981) [hereinafter cited as Case Comment, Torture as a Tort]; Note, Enforcement of International Human Rights in the Federal Courts after Filartiga v. Pena-Irala, 67 VA. L. REv. 1379 (1981); Comment, The Alien Tort Statute: United States Jurisdiction Over Acts of Torture Committed Abroad, 23 WM. \& MARY L. REV. 103 (1981).

84. Filartiga, 630 F.2d at 885 . Judge Kaufinan was joined in the opinion by Chief Judge Feinberg and Judge Kearse.

85. Id. at 889 . 
arrest, intimidation with death threats, and ultimate disbarment of Dr. Filartiga's attorney. ${ }^{86}$

In 1979 Dolly Filartiga, who had emigrated to the United States, learned that Pena-Irala was in New York. She filed suit on behalf of herself and her father against Peña-Irala, alleging subject matter jurisdiction under, inter alia, section 1350. The court's personal jurisdiction over the defendant was established by service of process on him while he was in New York. ${ }^{87}$ The district court dismissed the complaint on the ground that two prior Second Circuit cases ${ }^{88}$ required a finding that a nation's treatinent of its own citizens was beyond the reach of section 1350 jurisdiction..$^{89}$

The court of appeals reversed. In an opimion by Judge Kaufman, the court recognized the einergence through international consensus of a universal law of hunian rights. ${ }^{90}$ That law, according to the court, affords substantive rights to mdividuals ${ }^{91}$ and places limits on a state's treatment of its own citizens. ${ }^{92}$ The court thus rejected the Lopes/Dreyfus dicta that the prohibitions of international law do not reach a state's domestic affairs.

The Filartiga court held that section 1350's "law of nations" includes the einerging international law of huinan rights. ${ }^{93}$ The court einphasized that federal courts considering whether to assuine jurisdiction under the statute should interpret international law as it has evolved and exists at the time of the case, not as it existed in 1789.94 The court,

86. Id. at 878-80. The Second Circuit accepted as true the allegations of the complaint because the lower court dismissed for want of subject matter jurisdiction. Id. at 878 . On remand, the defendant's refusal to participate in the action resulted in a default judgment. Filartiga v. PeñaIrala, 577 F. Supp. 860 (E.D.N.Y. 1984). Thus the plaintiffs' allegations were never disproved in court.

87. Filartiga, 630 F.2d at 878-79.

88. In the first case, IIT v. Vencap, Ltd., 519 F.2d 1001 (2d Cir. 1975), Judge Friendly quoted Lopes's language excluding from the law of nations a nation's conduct affecting its owh citizens. Id. at 1015. See supra text accompanying notes 68-73. In the second case, Dreyfus v. Von Finck, 534 F.2d 24 (2d Cir.), cert. denied, 429 U.S. 835 (1976), the court declared outright that "violations of international law do not occur when the aggrieved parties are nationals of the acting state." 534 F.2d at 31 ; see supra text aecompanying notes $74-82$.

89. Filartiga, $630 \mathrm{~F} .2 \mathrm{~d}$ at 880 .

90. Id. at $878,881-84$.

91. Id. at 885. See Note, Terrorism as a Tort in Violation of the Law of Nations, 6 FordHAM INT'L L.J. 236, 252 (1982) ("By acknowledging international declarations on human rights as part of binding, customary international law, the Filartiga court implicitly recognized that international law must safeguard individual rights.") (footnote omitted).

92. Filartiga, 630 F.2d at 884.

93. See id.

94. Id. at 881. Judge Kaufman relied on two Supreme Court cases for his conclusion. The Paquete Habana, 175 U.S. 677 (1900), involved a standard of comity, the traditional prohibition against seizing an enemy's coastal fishing boats, that had ripened into "a settled rule of intcrnational law" by "the general assent of civilized nations." 175 U.S. at 694. In Ware v. Hylton, 3 U.S. (3 Dall.) 199 (1796), the Court had distinguished the "ancient" from the "modern" law of nations. 
at the same time, recognized limits on the federal courts' role in deciding cases under section 1350. The statute, as construed in Filartiga, is not an authorization to create new law; it is a grant of subject matter jurisdiction over claims based on rights already recognized under international law. ${ }^{95}$ Plaintiffs, the court stressed, inust be able to point to a clear substantive rule of international law, ${ }^{96}$ and that rule must reflect a consensus ainong the nations. ${ }^{97}$ Courts may discover that consensus by examining the sources histed in United States $v$. Smith. ${ }^{98}$

\section{After examination of the appropriate sources, ${ }^{99}$ the Filartiga court}

95. Filartiga, $630 \mathrm{~F} .2 \mathrm{~d}$ at 887 . The court suggested that $\S 1350$ was enacted as part of the framers' overall design to promote federal control over international affairs, $i d$, perhaps as a countermeasure to the availability of state courts for adjudication of transitory tort claims implicating foreign affairs, see id. at 885 . The grant of subject matter jurisdiction was constitutional, the court determined, because federal common law incorporated the law of nations when the Constitution was adopted. Id. at 886. But see infra note 142 (Judge Bork's rejection of this view). For a unore extensive discussion of the imcorporation approacl, see infra note 202 and accompanying text.

96. Filartiga, $630 \mathrm{~F} .2 \mathrm{~d}$ at 888 . For example, the Filartiga court used these grounds to distinguish IIT v. Vencap, Ltd., 519 F.2d 1001 (2d Cir. 1975), in which plaintiffs attempted to base a claim for fraud, conversion, and corporate waste in part on $\S 1350$. Judge Friendly there noted tliat the inclusion of the Eighth Commandment ("Thou shalt not steal") in every civilized nation's municipal law does not prove its imcorporation into the law of nations. IIT, 519 F.2d at 1015 . The Filartiga court also distinguished otler decisions involving a similar lack of consensus regarding the international legal rnle to be applied. See Filartiga, 630 F.2d at 888 \& n.23.

97. Judge Kaufman explained tliat "[t]lie requirement that a rule command the "general assent of civilized nations' to become binding upon them all is a stringent one. Were this not so, the courts of one nation miglit feel free to impose idiosyncratic legal rules upon others, in the name of applying international law." Filartiga, 630 F.2d at 881 (quoting The Paquete Habana, 175 U.S. 677, 694 (1900)). Indeed, Judge Kaufman attributed the dearth of cases in which $\S 1350$ jurisdiction lias successfully been invoked to this stringent requirement. The threshold requirement of a violation of the law of nations results in more dismissals than occur under other jurisdictional statutes. Id. at 887. Judge Kaufman therefore concluded that "tlie narrowing construction that the Alien Tort Statute has previously received refiects the fact tliat earlier cases did not involve such wellestablished, universally recognized norms of international law that are here at issue." Id. at 888; see supra note 96.

98. 18 U.S. (5 Wheat.) 153, 160-61 (1820). See supra note 70 and accompanying text. Nearly eighty years later the Court underscored the continuing validity of Smith's list of sources for ascertaining the law of nations, stating:

[W] decision, resort must be had to the customs and usages of civilized nations; and, as evidencc of these, to the works of jurists and coinmentators, who by years of labor, researcl and experience, have made themselves peculiarly well aequainted with the subjects of which they treat. Such works are resorted to by judicial tribunals, not for the speculations of their authors concerning what the law ought to be, but for trustworthy evidence of what the law really is.

The Paquete Habana, 175 U.S. 677, 700 (1900).

The Filartiga court noted that the approach outlined in Smith and The Paquete Habana accords with the provisions of the Statute of the International Court of Justice arts. 38 \& 59. Filartiga, 630 F.2d at $880-81$ \& n.8.

99. These included the United Nations Cliarter, United Nations resolutions, numerous international treaties and accords, national constitutions (including those of both Paragnay and the United States), and works of jurists. Filartiga, 630 F.2d at 880-84 \& n.16. Judge Kaufman also cited State Department reports and quoted from an amicus curiae brief submitted jointly by the 
found in the law of nations a "clear and unambiguous" prohibition of official torture. ${ }^{100}$ The court therefore held that section 1350 provided federal jurisdiction when, as in Filartiga, "an alleged torturer is found and served with process by an alien within our borders."101

On remand, ${ }^{102}$ the district court implemented the Second Circuit's holding. Peña-Irala, who had appeared through counsel for the appeal despite having been deported to Paraguay shortly after the initial district court decision, refused to participate further in the case. The district court disposed of two jurisdictional objections not resolved by the court of appeals, ${ }^{103}$ and then determined that plaintiffs had alleged facts sufficient to invoke subject matter jurisdiction under section $1350 .{ }^{104}$ The court ruled that punitive damages were appropriate, and entered a default judgment in excess of $\$ 10$ million agaimst Peña-Irala. ${ }^{105}$

\section{B. Tel-Oren v. Libyan Arab Republic}

Less than four years after the Filartiga opinion, the Court of Appeals for the District of Colunibia questioned the Second Circuit's construction of 28 U.S.C. $\S 1350$. In Tel-Oren v. Libyan Arab Repub$l i c^{106}$ the court considered a section 1350 claim arising out of a 1978 terrorist attack in Israel. The panel, which consisted of Senior Judge Robb and Judges Edwards and Bork, affirmed the disinissal of plaintiff's

Departments of State and Justice to the effect that, despite contrary state practice, there is currently among the nations a general recognition of the prohibition against torture. Id. at $884 \&$ n.15.

100. Id. at 884 .

101. Id. at 878. The Filartiga court was not faced with sovereign immunity issues, since the Filartigas did not name Paraguay in their suit, and since Peua-Irala did not claim diplomatic immunity. For a discussion of the sovereign immunity doctrine's application to human rights claims see infra note 294.

102. Filartiga v. Peña-Irala, 577 F. Supp. 860 (E.D.N.Y. 1984).

103. The district court held that it need not decline to exercise jurisdiction on the basis of the "act of state" doctrine, since (1) Paraguay had not notified the court that an adverse ruling would harm Paraguay's relationship with the United States, (2) the strong interuational consensus opposing torture reduced the likelihood that the district court might offend Paraguay, and (3) Paraguay had not ratified Peña-Irala's acts. Id. at 862; see infra notes $247-94$ and accompanying text. The court also rejected the defendant's forum non conveniens objection to jurisdiction. Filartiga, 577 F. Supp. at 862 .

104. The court decided that "tort" in $\S 1350$ referred to a wrong in violation of international law as mcorporated into United States common law. Therefore international law, not Paraguayan law, furnished the substantive principles to be applied. Filartiga, 577 F. Supp. at 862-63.

105. In justifying an award of punitive damages, the court read $\S 1350$ as a grant of authority to devise federal remedies for violations of international law. Choice-of-law principles required the court to apply Paraguayan law, but only to the extent that it did not prevent the enforcement of international law or conflict with the public policy of the United States. Id. at 863-64. Since punitive damages appeared necessary to enforce international law, see id. at $864, \S 1350$ provided a basis for an award of punitive damages. As Peũa-Irala has no assets in the United States, enforcement of the judgment apparently rests with the courts of Paraguay, and depends on pertinent standards for the execution of foreign judgments.

106. 726 F.2d 774 (D.C. Cir. 1984), cert. denied, 105 S. Ct. 1354 (1985). 
claim in a one-page per curiam opinion. However, the judges agreed on little beyond the result; they differed sharply in their rationales and filed 53 pages of concurring opinions. These opinions are significant because they represent the first appellate-court response to Filartiga. A coinparison of the Tel-Oren opinions with the Filartiga decision identifies the three issues which are the focus of this Comment: (1) whether section 1350 encompasses the law of nations as that body of law evolves; (2) whether section 1350 requires an express grant of a cause of action; and (3) whether the act of state and political question doctrines, or the separation-of-powers concerns they embody, necessarily bar the use of section 1350 in actions claiming violation of the international law of human rights. ${ }^{107}$

Tel-Oren involved a 1978 terrorist incident on the coast of Israel. Thirteen members of the Palestine Liberation Organization (PLO) landed by boat in Israel, hijacked a bus, and drove south on the main coastal highway, holding a number of hostages. When Israeli police finally stopped the bus, the terrorists fired at their hostages and blew up the bus with grenades. By the end of the massacre, the PLO terrorists had killed thirty-four adults and children, and wounded seventy-seven others. ${ }^{108}$ Survivors of the attack, the estates of persons killed in the attack, and representatives of the mimor's brouglit suit in district court in the District of Columbia, basing jurisdiction in part on section $1350 .{ }^{109}$

107. In addition to D'Amato, supra note 12, and Note, supra note 12, several commentators have recently discussed the Court of Appeal's Tel-Oren opinions. See Comment, After Tel-Oren: Should Federal Courts Infer a Cause of Action Under the Alien Tort Claims Act?, 3 DiCK. J. INT'L. L. 281 (1985) [hereinafter cited as Comment, After Tel-Oren] (arguing that federal courts should infer a "right to relief" from section 1350 by interpreting the statute either as itself conferring a right to relief or as authorizing courts to discern one in the law of nations); Case Comment, Tel-Oren v. Libyan Arab Republic: Redefining the Alien Tort Claims Act, 70 MiNN. L. Rev. 211 (1985) (arguing for Judge Edwards's interpretation that statute requires only allegation of tort that violates law of nations, and contending that procedural inechanisms will prevent any flood of hitigation froin ensuring); Note, Separation of Powers and Adjudication of Human Rights Claims Under the Alien Tort Claims Act, 60 WASH. L. REv. 697 (1985) [hereinafter cited as Note, Separation of Powers] (arguing that broad deference under separation-of-powers principles is both inappropriate, because of need for some judicial review in foreign affairs area, and unnecessary, because of alternative jurisdictional limitations on such actions).

These commentators generally concur in rejecting Judge Bork's approach and accepting that of Judge Edwards. Despite soine overlap in detail, this Comment differs broadly froin the above works in overall design. This Comment seeks to derive the jurisdictional requirements of section 1350 in the context of human rights cases, with special attention to the nature and location of the cause of action. The inquiry necessarily extends to all four of the opinions in Filartiga and Tel-Oren, and emphasizes assessinent of the judges' rationales in hight of both the statute's legislative and judicial history and the current state of international lav. Finally, this Comment concludes that a private right of enforcement may, in appropriate circuinstances, be inferred from the customary international law of human rights.

108. Tel-Oren, 726 F.2d at 799 (Bork, J., concurriug).

109. Tel-Oren v. Libyan Arab Republic, 517 F. Supp. 542 (D.D.C. 1981), affd, 726 F.2d 774 (D.C. Cir. 1984), cert. denied, 105 S. Ct. 1354 (1985). Plaintiffs asserted jurisdiction under 28 U.S.C. 
The plaintiffs, who included Israeh, Dutch, and American citizens, charged five defendants-the Libyan Arab Republic (Libya), the PLO, the Palestine Information Office (PIO), the National Association of Arab Americans (NAAA), and the Palestine Congress of North America (PCNA) - with inultiple tortious acts. ${ }^{110}$

The district court dismissed on several jurisdictional grounds. First, the court held that it lacked subject matter jurisdiction since the plaintiffs could not demonstrate a private cause of action sufficient to meet the requireinents of either 28 U.S.C. $\S 1331$ or 28 U.S.C. $\S 1350 .{ }^{111}$ In addition, the court found the allegation against the three Arab-American groups-the PIO, the NAAA, and the PCNA-too vague and conclusory to trigger the requireinents of section $1350 .{ }^{112}$ A Alternatively, the court found that all the claims, which alleged intentional torts, were barred by the local statute of limitations. ${ }^{113}$ In sum, because the plaintiffs had failed to deinonstrate that the law of nations, pertinent treaties, or section 1350 itself provided a cause of action, jurisdiction would not he under the Alien Tort Statute. ${ }^{114}$

\section{Opinion of Judge Edwards}

Judge Edwards was the sole ineinber of the panel to adopt the Filartiga construction of section 1350. He agreed with Judge Kaufinan's assertion in Filartiga that under the statute an alien need ouly show that defendant's actions violated a provision of the law of nations. ${ }^{115} \mathrm{He}$ endorsed four propositions froin the Filartiga opinion.

First, the "law of nations" is not stagnant and should be construed as it exists today among the nations of the world. Second, one source of that law is the customs and usages of civilized nations, as articulated by jurists and commentators. Third, international law today places limits on a state's power to torture persons held in custody, and confers "fundamental rights upon all people" to be free from torture. Fourth, section 1350

$\S \S 1350$ and 1331 (general federal question), and pursued these bases on appeal. Two other jurisdictional bases were asserted at trial but not on appeal: diversity of citizenship, 28 U.S.C. $\S 1332$ (1982), and the Foreign Sovereign Immunities Act of 1976, 28 U.S.C. $\S \S 1330,1602-1611$ (1982). Tel-Oren, 726 F.2d at 775 (per curiam).

110. Tel-Oren, 517 F. Supp. at 544-45. The alleged torts included, inter alia, assault, battery, false imprisonment, intentional infliction of emotional distress, and intentional infliction of cruel, inhuman, and degrading treatment. Id. at 550.

111. Id. at $548-49$.

112. Id. at 549 .

113. Id. at 550-51. The court also noted that the plaintiffs had not completed service on either Libya or the PLO. Id. at 545 n.1.

114. Id. at 549. Judges Edwards and Bork noted yet another jurisdictional bar. They pointed out that the Foreign Sovereign Immunities Act of 1976, 28 U.S.C. $\$ \S 1330,1602-1611$ (1982), precluded jurisdiction over Libya. Tel-Oren, 726 F.2d 774, $776 \mathrm{n} .1$ (Edwards, J., concurring); id. at 805 n.13 (Bork, J., concurring). See infra note 294.

115. Tel-Oren, 726 F.2d at 777 (Edwards, J., concurring). 
opens the federal courts for adjudication of the rights already recognized

by international law. ${ }^{116}$

Judge Edwards interpreted Filartiga as holding that section 1350 provided both the forum and the "right to sue" or "cause of action"117 for violations of the law of nations. ${ }^{118}$ He noted, however, that this jurisdiction was limited. It reached only acts traditionally warranting universal jurisdiction, such as piracy or slave trading, ${ }^{19}$ or offenses that coniparably violate current norms of international law. ${ }^{120}$

Because this formulation would necessarily involve courts in the "awesome duty"121 of deriving the apphicable liability standards from international law, Judge Edwards proposed an alternative. He suggested the approach illustrated by $A b d u l-R a h m a n$ Omar $A d r a,{ }^{122}$ under which the substantive right sued upon would be derived fron doniestic tort law of the Uinited States, while the "law of nations" element of the statute would serve solely as a source of subject niatter jurisdiction for the federal courts. ${ }^{123}$ This formulation would provide district courts with readily ascertainable substantive rules but, at the same time, would serve the statute's original purpose of "assur[ing] aliens access to federal courts to vindicate any incident which, if mishandled by a state court, might blosson1 into an international crisis."124 Judge Edwards pointed out that this approach raised problems of its own. ${ }^{125}$ Nevertheless, it shared with the

116. Id. (citations omitted).

117. Judge Edwards gave the two terms a single meaning for pnrposes of $\S 1350$ jurisdiction. Id. at 780 .

118. He stated:

The Second Circuit read $\$ 1350$ "not as granting new rights to aliens, but simply as opening the federal courts for adjudication of the rights already recognized by imternational law." Filartiga, 630 F.2d at 887. I construe this phrase to mean that aliens granted substantive rights under international law may assert them under $\S 1350$. This conclusion as to the meaning of this crucial yet obscure phrase results in part from the noticeable absence of any discussion in Filartiga on the question whether international law granted a right of action.

Tel-Oren, 726 F.2d at 780 n.5 (Edwards, J., concnrring).

119. Judge Edwards reported that "[h]istorically these offenses held a special place in the law of nations: their perpetrators, dubbed enemies of all mankind, were susceptible to prosecution by any nation capturing them." Id. at 781.

The doctrime of hostis humani generis (enemy of mankind) appears in Filartiga, where Judge Kaufman likened the inodern torturer to the pirate or slave trader of old. Filartiga v. Peña-Irala, 630 F.2d 876, 890 (2d Cir. 1980). This doctrine gave rise to both civil and criminal liability in any jnrisdiction where the perpetrator might be found. See Blum \& Steinhardt, supra note 12, at 56, 60 62; Dickinson, supra note 12 , at 29-30.

120. Tel-Oren, 726 F.2d at 781 (Edwards, J., concurring).

121. Id.

122. 195 F. Supp. 857 (D. Md. 1961). See supra notes 59-64 and accompanying text.

123. Tel-Oren, 726 F.2d at 782 (Edwards, J., concnrring).

124. Id.

125. First, Judge Edwards beheved that the Adra court failed to require a sufficient showing that defendants had violated the law of nations. He feared that a standard less rigorous than that employed in Filartiga would involve U.S. courts in "disputes wholly involving foreign states." Id. at 
Filartiga formulation one key characteristic: no requirement that plaintiffs plead a right to sue independent of the statute itself. ${ }^{126}$

Finally, although Judge Edwards adhered to the legal principles estabhished in Filartiga, he felt constrained to affirm the dismissal because of factual distinctions between the two cases. ${ }^{127}$ Although the law of nations prohibits torture by state actors or persons acting under color of state law, Judge Edwards found insufficient consensus that nonstate actors, such as the PLO, are subject to the saine rules. ${ }^{128}$ Similarly, Judge Edwards found a lack of consensus regarding terrorism, and he therefore concluded that terrorism is not a violation of international law. ${ }^{129}$

\section{Opinion of Judge Bork}

Judge Bork, on the other hand, voted to disiniss because plaintiffs could show no explicit grant of a cause of action and separation of powers primciples counseled against inferring one. ${ }^{130}$ Separation of powers principles inform two prudential doctrines, the act of state doctrine $e^{131}$ and the political question doctrine. ${ }^{132}$ From these doctrines Judge Bork

787-88. Second, Judge Edwards was concerned that the $A d r a$ rule did not adequately specify the necessary nexus between the international and the domestic tort. The Adra court's use of a "but for"

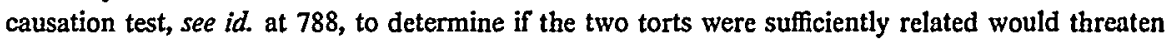
U.S. courts with a "potential deluge of actions." Id. Therefore, Judge Edwards suggested limiting these actions brought under the "law of nations" prong of $\S 1350$ to those for (1) domestic torts committed within the U.S. and injuring "substantial rights" under international law, (2) universal crimes wherever committed, and (3) torts committed by U.S. citizens abroad "where redress in American courts inight preclude international repercussions." Id.

126. Id.

127. Id. at 791 .

128. $I d$. at 776, 791-95. Although aware of fluetuations in the individual's status under international law since the drafting of $\$ 1350$ and willing to concede that "the trend in international law is toward a more expansive allocation of rights and obligations to entities other than states," Judge Edwards was unwilling, without guidance from the Supreme Court, to read the statute as encompassing torture by nonstate actors. $I d$. at 794-95.

129. Id. at 795-96.

130. Id. at 799 (Bork, J., concurring).

131. "The act of state doctrine in its traditional formulation precludes the courts of this country from inquiring into the validity of the public acts a recognized foreign sovereign power committed within its own territory." Banco Nacional de Cuba v. Sabbatino, 376 U.S. 398, 401 (1964). See infra notes 247-94 and accompanying text.

132. The modern formulation of the political question doctrine is found in Baker v. Carr, 369 U.S. 186 (1962), where the Supreme Court noted six elements of a political question.

Prominent on the surface of any case held to involve a political question is found a textually demonstrable constitutional commitment of the issue to a coordinate political department; or a lack of judicially discoverable and manageable standards for resolving it; or the impossibility of deciding without an initial policy determination of a kind clearly for nonjudicial discretion; or the impossibility of a court's undertaking independent resolution without expresssing lack of the respect due coordinate branches of government; or an unusual need for unquestioning adherence to a political decision already made; or the potentiality of embarrassment from multifarious pronouncements by various departments on one question. 
derived two considerations for the jurisdictional inquiry: (1) the potential for interference with the political branches' conduct of foreign affairs, and (2) the judiciary's competence to adjudicate issues implicating international relations. ${ }^{133}$ According to Judge Bork, either doctrine alone might bar the suit, but since their underlying considerations counseled against recognizing a cause of action, the result did not depend on the operation of either doctrine. ${ }^{134}$

Judge Bork based his definition of "cause of action" on a footnote in Davis v. Passman, ${ }^{135}$ which limited the power to enforce a statutory right to " "the class of hitigants that may, as a matter of law, appropriately invoke the power of the court." "136 Thus, in Judge Bork's view, separation of powers concerns made it inappropriate to provide plaintiffs with a cause of action in Tel-Oren.

The problems raised by plaintiffs' complaint seeined to implicate the rule laid down in Banco Nacional de Cuba v. Sabbatino ${ }^{137}$ by the Supreme Court:

[T] he greater the degree of codification or consensus concerning a particular area of international law, the more appropriate it is for the judiciary to render decisions regarding it, simce the courts can then focus on the application of an agreed principle to circumstances of fact rather than on the sensitive task of establishing a principle not inconsistent with the national interest or with international justice. It is also evident that soine aspects of international law touch more sharply on national nerves than do others; the less important the implications of an issue are for our foreign relations, the weaker the justification for exclusivity in the political branches. ${ }^{138}$

Judge Bork found hittle international consensus regarding a customary prohibition of either torture by nonstate actors or terrorism. ${ }^{139}$ Moreover, he found that the case presented serious potential for interference with the conduct of foreign relations. He therefore concluded that plaintiffs' case was inappropriate for federal-court adjudication, at least in the

Id. at 217; see infra notes 295-315 and accompanying text.

133. Tel-Oren, 726 F.2d at 802-03 (Bork, J., concurring).

134. Id. at 803-04. Unlike Judge Robb, Judge Bork declined to rest his decision squarely on the political question doctrine. He felt that Supreme Court precedent on the constitutional component of the doctrine was unclear. Id. at 822-23. Nonetheless, Judge Bork suggested that had he needed to reach the question, he would have dismissed the plaintiffs' action on political question grounds. See id. at 822 .

135. 442 U.S. 228 (1979).

136. Tel-Oren, 726 F.2d at 801 (Bork, J., concurring) (quoting Davis, 444 U.S. at 240 n.18). For a discussion of Judge Bork's use of this criterion, see D'Amato, supra note 12, at 101-05; infra text accompanying note 186.

137. 376 U.S. 398 (1964).

138. Id. at 428 .

139. Tel-Oren, 726 F.2d at 805-08 (Bork, J., concurring). 
absence of an express grant of a cause of action. ${ }^{140}$

Finding no clear grant of a cause of action in international law, ${ }^{141}$ in federal common law, ${ }^{142}$ or in the treaties rehed on by plaintiffs, ${ }^{143}$ Judge Bork turned to section 1350 itself. The statute, he argued, was no more than a grant of jurisdiction. The clearest proof of this was the effect that construing it expansively would have. Since treaties stand in parity with the law of nations by the terms of section 1350, allowing aliens into court on the inere pleading of a violation of the law of nations would necessitate like treatunent in the case of treaty violations. But this would allow thein to sue for treaty violations witlout slowing that they had a right to sue, a result that would "make all United States treaties effectively selfexecuting." 144

The better approach, in Judge Bork's view, is to construe section 1350 as providing jurisdiction over aliens' tort claims in only limited circunstances. In his view courts should assume jurisdiction under the statute only when a inodern statute, treaty, or executive agreeinent exphicitly grants a cause of action, or, perhaps, when aliens assert a violation of one of the three international crimes recognized in $1789 .{ }^{145}$ Since so little is known of section 1350's proper purpose, Judge Bork cautioned, courts slould assign the statute a very inodest role. By doing so they will avoid usurping "legislative" functions. ${ }^{146}$

140. Id. at 808.

141. Echoing the classical statist view, Judge Bork asserted that "as a general rule, international law does not provide a private right of action, and an exception to that rule would have to be deinonstrated by clear evidence that civilized nations had generally given their assent to the exception." Id. at 817 (citing Hassan, supra note 47, at 26-27).

142. Judge Bork rejected plaintiffs' contention that federal coinmon law provided a cause of action through its incorporation of international law. He distinguished between two types of "common law": (1) law with a nonstatutory and nonconstitutional source, and (2) court-made law, such as the common law of contract and tort. Judge Bork argued that international law is common law of the former type and therefore does not by itself provide a cause of action. Id. at 810.11.

143. After examining the thirteeu treaties relied on by plaintiffs, Judge Bork concluded that only five were binding on the United States; of these, he found three expressly non-self-executing and two impliedly so. $I d$. at 808-10.

144. Id. at 812 .

145. Id. at 813-16. The three offenses recognized as international crimes in 1789 were violation of safe-conducts, infringeinent of ambassadorial rights, and piracy. See 4 W. BLACKSTONE, COMMENTARIES *68.

146. Judge Bork explained that, on the issues raised by $\S 1350$, "we have, at the moment, no evidence what the intention of Congress was. When courts lack such evidence, to 'construe' is to legislate, to act in the dark, and hence to do many things that, it is virtually certain, Congress did not intend." Tel-Oren, 726 F.2d at 815.

Judges Bork and Edwards differed fundamentally in defining the role of the courts. What Judge Bork saw as "legislating," Judge Edwards interpreted as fulfilling the judicial duty to determine and apply the appropriate rule of decision. Indeed, Judge Edwards suggested that Judge Bork's separation of powers argument anounted to an insult to Congress, rather than a showing of deference. Pointing out that the law of nations does not provide a private right to sue even for the three offenses recognized by Blackstone, Judge Edwards stated:

Under [Judge Bork's] view, therefore, the clause in the statute had no meaning when 


\section{Opinion of Judge Robb}

Judge Robb affirmed dismissal because he found that the case presented a nonjnsticiable political question. He reasoned that the case involved judicially unmanageable standards because federal courts can neither determine the international legal status of terrorisin nor trace individual responsibility for any particular terrorist act. ${ }^{147}$ Moreover, adjudicating the case would involve the court in questions beyond both its coinpetence and its domain. ${ }^{148}$ The case was simply not susceptible to judicial handling, for botll practical and political reasons. ${ }^{149}$ Judge Robb never reached the jurisdictional issues discussed by his colleagues, dismissing them witli the observation that "[c]ourts ought not to serve as debating clubs for professors willing to argue over what is or what is not an accepted violation of the law of nations."150 In addition, lie saw no role for the international law of linman riglits in the interpretation of section $1350 .{ }^{151}$ These issues, he averred, are not proper subjects for adjudication, at least not before Congress and the President entrust thein

passed by Congress and none today. To enforce a construction that yields that result is not ouly to insult Congress, but inappropriately to place judicial power substantially above that of the legislature.

... Vigorously waving in one hand a separation of powers banner, ironically, with the other he rewrites Congress' words and renounces the task that Congress has placed before him.

Id. at 790 (Edwards, J., concurring).

147. As to the former point, Judge Robb joined his colleagues in finding a notable lack of international consensus regarding a proscription of terrorisin under international law. Id. at 823 . As to the latter point, Judge Robb stressed that an inquiry into the individual responsibility of the terrorists posed practical difficulties:

International terrorisin consists of a web that the courts are not positioned to unweave. To attempt to discover the reach of its network and the origins of its desigu may result in unintended disclosures imperiling sensitive diploinacy. This case attempts to focus on the so-called P.L.O. But which P.L.O.? Arafat's, Habash's, or Syria's? . . . As courts could never compel the allegedly responsible parties to attend proceedings much less to engage in a meaningful judicial process, they ought to avoid such imbroghos froin the beginning.

Id. at 823-24.

148. Judge Robb conceded the existence of "himited exceptions" to the general rule that the conduct of foreigu affairs lies beyond judicial competence, as when "the question is precisely defined" and "the facts are appropriately clear." Id. at 825. However, he considered Tel-Oren to be far beyond such possible exceptions and explained that in the area of foreign relations, the "traditional deference to the other branches has stemmed, in large part, from a fear of undue interference in the affairs of state, not only of this nation but of all nations." Id.

149. See id. at $823-24,826$.

150. Id. at 827 .

151. Judge Robb indicated that to entertain a claim for the violation of fundamental human rights would be tantamount to legislating.

We have no rehable evidence whatsoever as to what purpose this "legal Lohengrin," as Judge Friendly put it, was intended to serve. . . . We ought not to cobble together for it a inodern inission on the vague idea that international law develops over the years. Laws may evolve, but statutes ought not to mutate. To allow $\S 1350$ the opportunity to support future actions of the sort both countenanced in Filartiga and put forward here is to judicially will that statute a new life.

Id. (citation oinitted). 
to the judiciary. ${ }^{152}$

\section{Aftermath of Tel-Oren}

After their defeat in the court of appeals, the Tel-Oren appellants petitioned the United States Supreme Court for a writ of certiorari. The Court invited Solicitor General Rex E. Lee to file a brief expressing the views of the United States. ${ }^{153}$ The United States urged the Court to deny the petition. ${ }^{154}$ First, the Solicitor General argued, because of their length, coniplexity and divergent rationales, the Tel-Oren concurrences created no clear conflict ni the circuits. In fact, he suggested, it was as yet impossible to say what the law of the District of Columbia Circuit was on the issue of section 1350's construction. Thus, he concluded, "[l]eft undisturbed, that ambiguous judgment would have little, if any, precedential value."155 Moreover, the existence of alteruative, dispositive grounds for disimissal left undecided by the Tel-Oren panel ${ }^{156}$ also counseled demal of certiorari. Because these alternative grounds imght still niandate dismissal, a decision on the section 1350 issues might not affect the result. ${ }^{157}$

The Solicitor General also noted tliat pending litigation might soon resolve the issue of section 1350's construction. ${ }^{158}$ Anotlier panel of the District of Columbia Circuit Court of Appeals had recently lieard oral argunient and would soon render a decision in Sanchez-Espinoza v. Reagan. ${ }^{159}$ That case involved a suit agamst the President and other federal officials by United States Congressmen, Florida residents, and Nicaraguan citizens for claims arismg out of U.S. actions in Nicaragua. The Congressnien alleged disregard of Congress's right to declare war. The Florida residents alleged that operation of paramilitary camps in Florida violated the state's nuisance laws. The Nicaraguan plaintiffs sought both damages for injuries allegedly caused by United States-sponsored terrorist raids and an injunction against further U.S. military activity in Nicaragua. The Nicaraguan plaintiffs based their clainis on section 1350. The district court had dismissed the entire action primarily on political question grounds. ${ }^{160}$ But the Solicitor General urged that the appeal miglit either produce a inajority opmion representing the law of

152. Id.

153. 105 S. Ct. 72 (1984).

154. Brief for the United States as Amicus Curiae, Tel-Oren v. Libyan Arab Republic, 726 F.2d

774 (D.C. Cir. 1984), reprinted in 24 I.L.M. 427 (1985) [hereinafter cited as Tel-Oren Amicus Brief].

155. Id. at 9, 24 I.L.M. at 432 .

156. See supra text accompanying notes 112-13.

157. Tel-Oren Amicus Brief, supra note 154, at 12-14, 24 I.L.M. at 433-34:

158. Id. at 10-12, 24 I.L.M. at 432-33.

159. 568 F. Supp. 596 (D.D.C. 1983), affd, 770 F.2d 202 (D.C. Cir. 1985).

160. Id. at 602 . 
the circuit, or induce the circuit to rehear the case en banc. Either result would likely resolve the issue of section 1350's construction in the D.C. Circuit. Thus, any discrepancies between Filartiga and Tel-Oren either would be reconciled without need for Supreme Court review, or would ripen into a sharper conflict. ${ }^{161}$ The Supreine Court denied the Tel-Oren certiorari petition without comment. ${ }^{162}$

The subsequent decision in Sanchez-Espinoza v. Reagan ${ }^{163}$ did not resolve the conflict between Filartiga and Tel-Oren. Judge Scalia, joined by Judges Tamm and Ginsburg, affirmed the district court's dismissal on a number of grounds. With regard to the aliens' section 1350 claims against the defendants as individuals, Judge Scalia suggested that the statute "may conceivably have been ineant to cover only private, nongovernmental acts that are contrary to treaty or the law of nations."164 But he could find no treaty outlawing the challenged acts when committed by private individuals; customary international law similarly failed to identify any prohibition of the challenged conduct. ${ }^{165}$ Yet, Judge Scalia's language was significant. He concluded that the law of nations "does not reach private, non-state conduct of this sort for the reasons stated by Judge Edwards in Tel-Oren." 166 He thus left open the question whether customary international law would provide actionable private rights in appropriate cases.

Judge Scalia next examined the claims against defendants in their official capacities, and concluded that domestic sovereign immunity barred these claims. He explained that the doctrine operates to preclude judicial interference with the government's administration of domestic affairs, at least in the absence of official conduct that is unlawful or unconstitutional. ${ }^{167} \mathrm{He}$ did not find the waiver of immunity needed to allow plaintiffs' claim for monetary dainages. ${ }^{168} \mathrm{He}$ held that it would have been an abuse of discretion to grant the injunctive rehef sought, and concluded that the district court had properly dismissed the section 1350 claims. ${ }^{169}$

Judge Scalia went out of his way to explain that the holding in Sanchez-Espinoza did not necessarily conflict with Filartiga.

Since the doctrine of foreign sovereign immunity is quite distinct from the doctrine of domestic sovereign immunity that we apply here, being

161. Tel-Oren Amicus Brief, supra note 154, at 11-12, 24 I.L.M. at 433.

162. 105 S. Ct. 1354 (1985).

163. 770 F.2d 202 (D.C. Cir. 1985).

164. Id. at 206.

165. Id. at 206-07.

166. Id. (emphasis added); see supra note 128 and accompanying text.

167. Sanchez-Espinoza, 770 F.2d at 207.

168. Id.

169. Id. at 207-08. 
based upon considerations of international comity . . . rather than separation of powers ... it does not necessarily follow that an Alien Tort Statute suit filed against the officer of a foreign sovereign would have to be dismissed. Thus, nothing in today's decision necessarily conflicts with the decision of the Second Circuit in Filartiga v. Peña-Irala . . . 170

Thus, Sanchez-Espinoza does not sharpen the issues raised by Tel-Oren. The questions raised by a comparison of the Filartiga and Tel-Oren opinions remain unresolved. ${ }^{171}$

\section{III}

ANALYSIS

As the first major judicial response to Filartiga, the Tel-Oren concurrences suggest a host of issues related to aliens' suits grounded in international law. This Comment seeks to demonstrate that section 1350 can and should, in appropriate circumstances, support an alien's clain in tort for the violation of certam fundamental huinan rights. The analysis will address three issues pertment to this demonstration. This section will first examine whether the statute einbraces the law of nations as that law evolves. Next, the analysis will examine the cause of action requirement imposed by Judge Bork, and will propose an interpretation of section 1350's jurisdictional requirements that is true to the statute's apparent origins and purpose while recognizing the dynamic state of international law today. Fimally, this section will look beyond the mechanics of the cause of action requirement to the underlying separation of powers and political question objections raised by Judges Bork and Robb. An analysis of the act of state and political question doctrines will reveal that neitler doctrine precludes the use of section 1350 as a basis for jurisdiction over claims based on violations of judicially cognizable liuman rights under customary imternational law.

170. Id. at $207 \mathrm{n} .5$ (citations omitted). The court affirmed dismissal of the Congressmen's war powers claim on political question grounds. Id. at 210 . In a brief concurrence, Judge Ginsburg urged dismissal of that claim as unripe, since there was as yet no "constitutional impasse" between the two political branclies requiring judicial resolution. Id. at 210-11 (Ginsburg, J., concurring). Finally, the court affirmed dismissal of the Florida residents' nuisance claim for lack of pendent jurisdiction. Id. at 210 .

171. Similarly, a district court recently discussed, without resolving, differences in the Tel-Oren opinions. In Von Dardel v. USSR, 623 F. Supp. 246 (D.D.C. 1985), two Swedish citizens sued the Soviet Union for the alleged unlawful seizure, imprisonment, and possible death of Swedish diplomat Raoul Wallenberg. Because these alleged violations of diplomatic immunity established subject matter jurisdiction under even the narrowest view of $\S 1350$ proffered in Tel-Oren, the court found it imnecessary to choose from among the three interpretations. Id. at 259 . The $\$ 1350$ discussion was only dicta, however, because tle court assumed jurisdiction under the Foreign Sovereign Immunities Act of 1976. See infra note 294. 


\section{A. Section 1350's "Law of Nations" as an Evolving Body of Law}

The threshold issue raised by the Filartiga and Tel-Oren opinions is whether "the law of nations" under section 1350 means international law as it may evolve, or as it existed in 1789. Specifically, the issue is whether section 1350 is available to support claims based on the customary international law of human rights. If the statute's scope is limited to violations of international law that existed in 1789 , then all human rights claims brought under section 1350 will fail.

Judges Kaufinan and Edwards accepted the adaptation of section 1350 to the newly evolved international law of human rights. Judge Bork clainied to accept the proposition advanced by Judge Edwards that "the 'law of nations' is not stagnant and should be construed as it exists today among the nations of the world." 172 He nonetheless would bar all human rights claims from the workings of the statute. ${ }^{173}$ Judge Robb did not reach the issue, but suggested that the assumption of section 1350 jurisdiction over human rights clainis would "judicially will that statute a new life."174

Perhaps the strongest argument for the construction adopted by Judges Kaufman and Edwards is the language of the statute itself. Section 1350 by its terms addresses cases involving "aliens" and violations of "the law of nations." It thus incorporates by reference a body of law which must change. For the law of nations is now, and was in 1789, evolutionary in nature; it is derived from both treaties and the changing customary practice of nations. ${ }^{175}$

172. Tel-Oren v. Libyan Arab Republic, 726 F.2d 774, 777 (D.C. Cir. 1984) (Edwards, J., concurring), cert. denied, 105 S. Ct. 1354 (1985); see id. at 820 (Bork, J., concurring) (adopting first three propositions derived from Filartiga by Judge Edwards).

173. Judge Bork argued that "[i]t is important to remember that in 1789 there was no concept of international human rights; neither was there, under the traditional version of customary international law, any recognition of a right of private parties to recover." He concluded that "[c]learly, cases like this and Filartiga were beyond the framers' contemplation." Id. at 813 .

To explain the facial discrepancy between these remarks and his avowed agreement that the law of nations should be construed as it exists today, Judge Bork suggested that the evolution of the law of nations to include a customary rule prohibiting torture is "a difference in degree so enormous as to be a difference in kind." Id.

174. Id. at 827 (Robb, J., concurring).

175. The Departments of State and Justice stressed this point in the amicus curiae memorandum they submitted jointly upon the request of the Filartiga court. See Memorandum for the United States as Amicus Curiae, Filartiga v. Peña-Irala, 630 F.2d 876 (2d Cir. 1980), reprinted in 19 I.L.M. 585 (1980) [hereinafter cited as U.S. Filartiga Memorandum]. The government stressed the evolutionary nature of customary international law and analogized to the framers' grant of maritine jurisdiction.

There is no reason to believe that Congress intended to freeze the meaning of the law of nations in this statute as of 1789 , any more than it intended the simultaneous grant of jurisdiction over maritime actions to be limited to maritime law as it then existed. Since the law of nations had developed in large measure by reference to evolving customary practice, the framers of the first Judiciary Act surely anticipated that international law would not be static after 1789 . 
Moreover, what is known of Congress's intentions compels the interpretation that the statute embraces all violations of international law, not just those existing in 1789. The 1789 statute provided concurrent jurisdiction to federal district courts as an alternative forum to state common law courts in order to further uniform interpretation and application of the law where international issues are concerned. An interpretation limiting section 1350's usefulness to the three violations of the law of nations cited by Blackstone and leaving all new rules of international law to be adjudicated in the coinpetent state courts would thwart this purpose. ${ }^{176}$

The meaning of the phrase, "violation of the law of nations," cannot be frozen at any period; the term must be keyed to the current state of custoinary international law. The existence of a customary international law of human rights is today generally accepted. ${ }^{177}$ Courts should therefore interpret section 1350's jurisdictional requirement of a violation of the law of nations to include violations of internationally recognized human rights, provided those rights meet stringent criteria quahifying them for judicial cognizance. ${ }^{178}$

\section{B. The Cause of Action Requirement}

In Davis v. Passman, ${ }^{179}$ the Supreme Court distinguished two meanings for the term "cause of action." The traditional meaning, referring "roughly to the alleged invasion of 'recognized legal rights' upon which a hitigant bases his claim for rehief," 180 arrived as a legal term of art in the Field Code of 1848. The second meaning is a more recent product of Supreme Court cases concerning who can enforce statutorily created rights. ${ }^{181}$ The latter meaning identifies those parties who may appropriately invoke the power of the court to enforce the rights in question as having a cause of action. ${ }^{182}$ Judge Bork, in requirmg an express grant of

\section{U.S. Filartiga Memorandum, supra, at 588 (footnote omitted).}

176. See id. at 588-89. The extension of general federal question jurisdiction in 1875, coupled with the Sabbatino rule that interpretations of international law are federal questions, has mitigated the threat of conflicting state interpretations. See supra text accompanying notes 43-45. These more recent developments, however, do not affect analysis of the framers' understanding of the scope of "the law of nations."

177. See supra notes 23-32 and accompanying text; see also Nuclear Tests (Austl. v. Fr.), 1974 I.C.J. 253, 303 (Judgment of Dec. 20) (Petrén, J., concurring) (acknowledging post-World War II emergence of international law of human rights).

178. See infra notes 211-22 and accompanying text.

179. 442 U.S. 228 (1979).

180. Id. at 237 (footnote omitted).

181. See, e.g., Cannon v. University of Chicago, 441 U.S. 677 (1979) (private right of action under Title IX for sex discrimination); Securities Investor Protection Corp. v. Barbour, 421 U.S. 412 (1975) (no private right of action under Securities Investor Protection Act).

182. Davis, 442 U.S. at 239. The Davis Court attempted to distinguish this second type of "cause of action" from the notion of "standing." Id. at 239 n.18. Judge Bork conceded that in cases 
a cause of action, apparently focused on the second meaning. This section argues that Judge Bork's proposed requirement is unwarranted. It then analyzes how and in what circumstances violations of international human rights provide plaintiffs with a cause of action in the traditional sense. Finally, the analysis suggests that even if the second meaning is employed, an alien plaintiff would still qualify as a proper litigant.

\section{Judge Bork's Proposed Requirement of an Express Cause of Action}

Of the four judges writing in Filartiga and Tel-Oren, ouly Judge Bork would require plaintiffs mvoking section 1350 to demonstrate an express grant of an independent "cause of action" or "right to sue." Judge Bork would require an express grant in a self-executing United States treaty, a statute, an executive agreeinent, or international law. The purpose of this requirement, Judge Bork stressed, is not ouly to ensure that the plaintiff is an appropriate hitigant before the courts but to overcome separation of powers concerns. ${ }^{183}$ For the reasons discussed below, this requirement is unjustifiable.

Commentators have already noted the nost powerful argument against Judge Bork's position: it effectively nu!lifies the entire "law of nations" prong of the statute. ${ }^{184}$ As Judge Edwards pointed out, the law of nations does not create or define the civil actions available to plaintiffs. ${ }^{185}$ It creates or acknowledges substantive rights, and allows individual states to decide how to provide for their enforcement. Thus, to the extent that Judge Bork would require an explicit grant of a private right to sue under international law, plaintiffs are faced with an impossible task.

Judge Bork's opimion raises other problems. He used "cause of action" in the sense of a statutorily derived right. There is no reason, however, to apply this definition beyond cases involving newly created statutory rights intended to protect a limited class of persons. The international law of human rights suggests that fundamental human rights are analogous to constitutional rights, vesting ini all persons by reason of their very existence. ${ }^{186}$ Judge Bork's use of the latter Davis v. Passman

like Tel-Oren the plaintiff without a cause of action "is more like a plaintiff who lacks standing than he is like a plaintiff facing a motion to dismiss for failure to state a claim." Tel-Oren, 726 F.2d at 803 n.8 (Bork, J., concurring). Professor D'Amato finds it "hard to discern a real difference" between the two concepts. D'Amato, supra note 12, at $101 \mathrm{n} .23$.

183. Tel-Oren v. Libyan Arab Republic, 726 F.2d 774, 804, 808 (D.C. Cir. 1984) (Bork, J., concurring), cert. denied, $105 \mathrm{~S}$. Ct. 1354 (1985).

184. See D'Amato, supra note 12, at 95-101; Note, supra note 12, at 950.

185. Tel-Oren, 726 F.2d at 778 (Edwards, J., concurring).

186. For instance, the Universal Declaration of Human Rights provides that "[e]veryone is entitled to all the rights and freedoms set forth in this Declaration, without distinction of any kind, such as race, colour, sex, language, religion, politieal or other opinion, national or social origin, property, birth or other status." UDHR, supra note 25 , art. 2, p. 72. See also RESTATEMENT 
"cause of action" definition seems intended to bar certain plaintiffs from having a court decide whether the allegations, if true, constitute a traditional cause of action. The very notion of "human rights" belies the appropriateness of this limitation, since every person possesses them.

The requirement of an express independent grant of a cause of action also contravenes precedent. The earliest treatments of section 1350 obviously contain no inention of the post-1848 term "cause of action." But, even in inore recent treatinents the requireinent has posed no obstacle to jurisdiction. In 1907 Attorney General Bonaparte opined that section 1350 provided at least a forum, and perhaps a right of action; he made no mention of the need for an express grant of a cause of action. ${ }^{187}$ Even cases dismissing section 1350 claims have generally done so for failure to show a "violation of the law of nations" rather than for lack of an express cause of action. ${ }^{188}$

To point out the shortcomings in Judge Bork's approach is not, however, to ignore the separation of powers concerns which contributed to the proposed express cause of action requirement. Rather, it is to relegate them to their proper place as policy considerations which may in individual cases require judicial abstention. In this capacity they will be discussed later in this Comment.

\section{Cause of Action: Traditional Definition}

There are two grounds for inferring that ahen plaintiffs have a right to enforce international human rights in federal court under section 1350. First, the statute has been interpreted to provide alien plaintiffs both a forum and a cause of action. Second, commentators have suggested that the judicially enforceable substantive right arises under international law, and the incorporation of that law into the law of the United States provides the necessary bridge to the doinestic legal system. ${ }^{189}$

(REVISED) OF THE FORE1GN RELATIONS LAW OF THE UNITED STATES $\$ 701$ comment a (Tent. Draft No. 6, 1985) (" 'Human rights' refers to freedoms, immunities and benefits which, by widely accepted contemporary values, every human being should enjoy in the society in which the individual hives or to whose jurisdiction he or she is otherwise subject.").

187. See 26 Op. Att'y Gen. 250, 252 (1907); see also supra notes 54-58 and accompanying text.

188. See supra note 65 and accompanying text.

189. Under a third interpretation of the statute's requirements, plaintiff's cause of action arises under the domestic tort law of the United States. The law of nations serves only to provide access to federal court, while doinestic tort law provides the substantive right and pertinent standard of liability. This is the approach adopted by the court in Adra v. Clift, 195 F. Supp. 857 (D. Md. 1961), and elaborated in Judge Edwards's opinion in Tel-Oren v. Libyan Arab Republic, 726 F.2d 774, 78689 (D.C. Cir. 1984) (Edwards, J., concurring), cert. denied, 105 S. Ct. 1354 (1985). See supra notes 59-64, 122-25 and accompanying text. This Comment rejects the Adra approach. There is little in the pre-Adra jurisprudence to support the correctness of its bifurcation of the law of nations and domestic tort law. More importantly, nothing in the language of $\S 1350$ supports this bifurcation. Although the approach is consistent with the expressed goal of ensuring aliens' access to federal court in cases of diversity, it ignores the concomitant purpose of fulfilling the nation's obligation to 
Under the latter view, the precise source of the cause of action is probleinatic. One might argue that it arises under international law, which creates or recognizes the substantive right. Equally plausibly, one might locate it in the federal common law, which incorporates international law and gives it effect in the dornestic legal system.

\section{a. Cause of Action under Section 1350}

Attorney General Bonaparte apparently adopted the first approach in 1907 when he suggested that section 1350 would provide both a forum and a cause of action for Mexican nationals injured by an American coinpany's wrongful altering of the Rio Grande boundary. ${ }^{190}$ Under this view, section 1350 does inore than simply grant jurisdiction. The statute simultaneously creates a foruin and a cause of action for aliens to redress injuries arising from violations of either United States treaties or the law of nations. Judge Edwards adopted this approach and assumed that Judge Kaufman had as well, ${ }^{191}$ although the Filartiga opinion does not address the point exphicitly. Judge Bork rejected the position on grounds to be examined presently.

The chief justification for the Edwards/Bonaparte approach to section 1350 is that it allows aliens to sue under section 1350 directly, without Judge Bork's proposed requireinent of an express cause of action. But there is a second advantage. If one starts, as Judge Edwards did, from the premise that international law never implies a private right to sue, ${ }^{192}$ this approach inakes operative the section 1350 prong which requires a violation of the law of nations. It also reconciles the statute's operation under a statist conception of international law with the probable operation originally intended by Congress, which adopted the statute at a time when individuals evidently could sue under the law of nations. ${ }^{193}$

Nevertheless, this approach is subject to several objections, one of

observe and enforce the law of nations. Finally, trying to fit certain violations of the customary international law of human rights, such as official torture, into the traditional tort categories of state common law, is an artificial exercise.

190. See supra notes 5458 and accompanying text. Attorney General Bonaparte's opinion is susceptible to an alternate reading which supports the view, discussed infra at text accompanyiug notes 202-26, that the cause of action arises under international law or a United States treaty, and $\S 1350$ only provides jurisdiction. See supra note 58 .

191. Tel-Oren, 726 F.2d at 780 (Edwards, J., concurring) (approving "the view of the Second Circuit ... that $\S 1350$ itself provides a right to sue for alleged violations of the law of nations") (footnotes omitted).

192. See id. at 779 n.4 (Edwards, J., concurring). At least one district court has adopted the premise and reasoning of Judge Edwards. See Handel v. Artukovic, 601 F. Supp. 1421 (C.D. Cal. 1985) (in $\S 1350$ action alleging acts of genocide by former official of Nazi puppet state, held that customary international law rules are not directly enforceable).

193. See supra note 16; see also supra text accompanying notes 51-53. 
which merits special attention because of its potential to confuse the debate regarding section 1350. Judge Bork regarded as an "insuperable obstacle" that the Edwards view of section 1350 would create a private cause of action for violations of both the law of nations and United States treaties. His argument can be summarized as follows: Because the law of nations and Umited States treaties stand in facial parity in the statute, they must be treated similarly under the statute. Thus, to infer a private cause of action for violations of the law of nations necessitates doing the sanie for all violations of United States treaties. This would effectively render all United States treaties "self-executing"194 and contravene almost 200 years of jurisprudence. ${ }^{195}$

This objection is not compelling. As Judge Edwards noted, the objection confuses parity as a source of jurisdiction with parity as a source of enforceable rights. ${ }^{196}$ Moreover, as comnientary has demonstrated, the argument is grounded on a misconception of the nature of treaty violations. ${ }^{197}$ Non-self-executing treaties bind only the states as parties, and consist of promises to enact iniplementing legislation. Violation of those treaties will not injure individuals directly enough to enable them to sue, ${ }^{198}$ and therefore will not be of use to plaintiffs in section 1350 tort suits. ${ }^{199}$ Judge Bork's fears for the integrity of United States

194. Self-executing treaties either explicitly or implicitly create rights that are directly enforceable under domestic law. Non-self-executing treaties require implementing legislation by the signatories before individuals may use them as a basis for relief. This distinction is not disputed. See Foster v. Neilson, 27 U.S. (2 Pet.) 253, 314 (1829); $c f$. Dreyfus v. Von Finck, 534 F.2d 24, 30 (2d Cir.) ("It is only when a treaty is self-executing, when it prescribes rules by which private rights may be determined, that it may be relied upon for the enforcement of such rights.") (citations omitted), cert. denied, 429 U.S. 835 (1976). See also supra note 18. Just how to identify the distinction in a specific treaty, however, is less clear. See Lillich, supra note 25, at $239 \mathrm{n} .7$; Riesenfeld, The Doctrine of Self-Executing Treaties and U.S. v. Postal: Win at Any Price?, 74 AM. J. INT'L L. 892 (1980); Schneebaum, The Enforceability of Customary Norms of Public International Law, 8 BROOKLYN J. INT'L L. 289, 293-94 (1982). One court has found the determination to rest on several "contextual" factors, including the purposes of the treaty, the objectives of its creators, the availability and feasibility of institutions for direct implementation, and the immediate and long-range social consequences of self-execution or lack of self-execution. People of Saipan ex rel. Guerrero v. United States Dep't of Interior, 502 F.2d 90, 97 (9th Cir. 1974), cert. denied, 420 U.S. 1003 (1975). Schneebaum propcses that both treaty and customary international legal rights be analyzed under a single set of criteria. See Schneebaum, supra, at 300; see also infra note 218.

195. See Tel-Oren, 726 F.2d at 820 (Bork, J., concurring).

196. "Unlike the law of nations, which enables each state to make an independent judgment as to the extent and method of enforcing internationally recognized norms, treaties establish both obligations and the extent to which they shall be enforceable." Id. at 778 n.2. (Edwards, J., concurring).

197. See D'Amato, supra note 12, at 98-100.

198. Professor D'Amato suggests that the individual will at best have a claim against Congress analogous to a shareholder's derivative lawsuit, but concludes that American concepts of standing, pchitical question, and Congress's constitutional right to legislate or not wculd likely bar such a suit. Id. at 99.

199. See id. at 100 ("[O]nly governments can violate non-self-executing treaties and, if and when they do, the 'violation' consists only of failure to enact implementing legislation and not the sorts of 
treaty law are therefore misplaced.

There are other, more compelling objections to Judge Edwards's approach. First, as Judge Bork pointed out, the Supreme Court has averred that the "Judicial Code, in vesting jurisdiction in the District Courts, does not create causes of action, but only confers jurisdiction to adjudicate those arising from other sources which satisfy its limiting provisions." ${ }^{200}$ More fundamentally, Judge Edwards's approach contradicts the notion underlying a cause of action. In its traditional sense, a cause of action is the alleged infringement of a recognized substantive legal right. Not even Judge Edwards would suggest that section 1350 creates substantive legal rights. Rather, they originate in the law of nations. Courts must therefore look to international law, not section 1350 , to determine whether there has been a violation of plaintiffs' human rights.

These problems may be avoided. Locating an implied right of enforcement in international law, such as apparently existed under the older law of nations, ${ }^{201}$ makes it possible to treat section 1350 as a simple jurisdictional grant and to give the statute full operational effect. This is the objective of the second approach to section 1350 .

\section{b. Cause of Action Under International Law as Incorporated into Federal Common Law}

An alternative to the Edwards/Bonaparte interpretation of section 1350 as providing both a forum and a cause of action is to locate the cause of action in the law of nations itself. Customary international law in certain circumstances recognizes judicially enforceable mdividual rights. The "incorporation" of international law into federal common law would inake these rights directly enforceable in United States district courts under section $1350 .{ }^{202}$

substantive violations of treaty principles that might be helpful to individual plaintiffs in tort actions under section 1350."). The recent case of Frolova v. USSR, 761 F.2d 370 (7th Cir. 1985), supports Professor D'Amato's view. Though not a $\$ 1350$ action because the plaintiff was a United States citizen, Frolova involved tort claims based in part on the Helsinki Accords. The court held that the Accords are non-self-executing, stating that they "create obligations on the signatory countries and establish goals which the nations will try to reach on their own." Id. at 375.

200. Tel-Oren, 726 F.2d at 811 (Bork, J., concurring) (quoting Montana-Dakota Util. Co. v. Northwestern Pub. Serv. Co., 341 U.S. 246, 249 (1951)).

201. See supra notes $14-16$ and accompanying text.

202. The jurisprudential basis for this incorporation of international law is still the subject of analysis and dispute. Some commentators argue that customary international law is part of federal common law. See Blum \& Steinhardt, supra note 12, at 57-58. For others, it is not part of, but hike, federal common law. See Henkin, International Law as Law in the United States, 82 Mich. L. REv. 1555, 1561-62 ("[F]ederal courts find international law rather than make it . . .."). Another view, noted by Schneebaum, bases incorporation on the rule that international law binds a state acting through its judiciary absent legislative expression that it does not consent to be bound. See Schneebaum, supra note 194, at 289 n.3. While the precise rationale may be disputed, the rule of incorporation is well settled. In 1900 the Supreme Court held that "[i]nternational law is part of our 
The incorporation approach is consistent with the Filartiga opinion. Judge Edwards, however, apparently rejects it on the ground that international law never implies a right to sue. ${ }^{203}$ Judge Bork rejected the incorporation approach for two reasons. He agreed with Judge Edwards that international law does not provide a cause of action, ${ }^{204}$ and added that federal common law does not either. ${ }^{205}$ Nonetheless, the incorporation approach is faithful to the concerns of section 1350 , consistent with international legal principles, and flexible enough to accommodate the growth of international law.

The government argued for the incorporation construction of section 1350 in its a1micus memorandum to the Filartiga court. It argued that the traditional view that only states have legal competence under the law of nations "no longer reflects the state of customary international law."206 After noting that individuals have traditionally been able to sue to enforce their rights under international law in certain situations, ${ }^{207}$ the government urged that the recently evolved international law of human rights similarly vouchsafes individuals a right of enforcement in certain circuinstances, which other nations' courts have already recoguized. ${ }^{208}$ The government argued that, since United States law incorporates international law, "an individual's fundainental human rights are in certain situations directly enforceable in donnestic courts."209 Under this view, international law provides the substantive, judicially enforceable right, and federal common law provides the mechamism and constitutional basis for enforcement. ${ }^{210}$

law, and must be ascertained and adininistered by the courts of justice of appropriate jurisdiction, as often as questions of right depending upon it are duly presented for their determination." The Paquete Habana, 175 U.S. 677, 700 (1900).

203. See Tel-Oren, 726 F.2d at 777-78, 779 n.4 (Edwards, J., concurring).

204. Id. at 816-19 (Bork, J., concnrring).

205. Id. at 811 .

206. U.S. Filartiga Memoranduun, supra note 175 , at 602 .

207. Id. (citing The Paquete Habana, 175 U.S. 677 (1900), where a shipowner was permitted to sue to recover both ship and damages when his ship had been seized on the high seas in violation of international law).

208. It stated:

The more recently evolved international law of human rights sinilarly endows individuals with the right to invoke international law, in a competent forum and under appropriate circuunstances. The highly respected Constitutional Court of Germany has recognized this right of individuals. The court declared that, although "contemporary generally recognized principles of international law include only a few legal rules that directly create rights and duties of private individuals by virtue of the interuational law itself," an area in which they do create such rights and duties is "the sphere of the minimuin standard for the protection of human rights."

Id. at 602-03 (footnote omitted).

209. Id. at 603 .

210. Wright and Miller state:

Insofar as it refers to a treaty of the United States [\$ 1350] is certainly within the constitutional grant of power over cases arising under treaties of the United States. To the extent, however, that it allows suit for a tort cominitted in violation of the law of nations, 
Not all human rights qualify as fundamental human rights capable of judicial enforcement. Only those rights that satisfy certain criteria as customary international norms are suited for enforceinent under section 1350. Those criteria are universality, specificity, and obligatory character. ${ }^{211}$ Only human rights universally recognized by the community of nations have been adopted as custoinary rules of international law. ${ }^{212}$ Rights must be articulated with specificity ${ }^{213}$ to insure that agreement as

its constitutional basis as of 1789 is far from clear, but today it is not difficult to conclude that customary international law is a part of federal common law for purposes of federal question jurisdiction.

13B C. Wright, A. Miller \& E. Cooper, Federal Practice and Procedure ๆ 3585, at 32829 (1984) (footnotes omitted) (citing Filartiga).

Under this reasoning, of course, these suits also may be sustainable under 28 U.S.C. $\$ 1331$, the general federal question provision. See $1 \mathrm{~S}$. Riesenfeld \& G. Hauck, Cases and Materials on International Law 229 n.3 (1985) (course reader, Boalt Hall School of Law). The explanation for enactment of $\S 1350$ despite the apparent overlap with general federal question jurisdiction is that the latter was not extended to federal district courts until 1875. See supra note 75. Given the Supreme Court's reiteration, in Banco Nacional de Cuba v. Sabbatino, 376 U.S. 398 (1964), that international law is part of federal common law, and its ruling that imterpretations of customary international law are

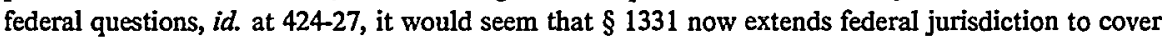
torts violating international law. One objection to this view is that $\S 1331$ requires plaintiffs to identify either an express or an implied right to sue under international law, but that international law neither expresses nor implies such a right. This is Judge Edwards's objection. Tel-Oren, 726 F.2d at 779-80 n.4 (Edwards, J., concurring). Accord Handel v. Artukovic, 601 F. Supp. 1421 (C.D. Cal. 1985). If, however, international law does imply a cause of action, as this Comment argues, then simultaneous $\S 1331$ jurisdiction exists. Alien plaintiffs suing for torts in violation of international law would have a choice of bases for jurisdiction. Cf. Filartiga v. Peña-Irala, 630 F.2d 876, 887 n.22 (2d Cir. 1980) (alien plaintiffs might have a choice between $\S 1350$ and $\S 1331$ ). Nonetheless, to date the debate has focused on $\S 1350$.

211. These criteria are derived from three sources: the U.S. Filartiga Memorandum, supra note 175, at 589; Blum \& Steinhardt, supra note 12, at 87-90; Schneebaum, supra note 194, at 301-02.

212. See Schneebaum, supra note 194, at 301-02 \& n.62. Because of the requirement of universal recognition, the suggestion that the lack of consensus about terrorism need not preclude its being an international tort within the meaning of $\S 1350$, see Note, supra note 91 , at 243 , is mistaken. Once having determined the lack of consensus, Judge Edwards reached the proper result in Tel-Oren in voting to dismiss the claims concerning both terrorism and nonofficial torture. See Tel-Oren, 726 F.2d at 795-96 (Edwards, J., concurring). Significantly, recent U.N. votes overwhelmingly condemning terrorism-albeit under a loose definition of that term-may foreshadow the emergence of consensus sufficient to establish an international legal prohibition of terrorism. See N.Y. Times, Dec. 19, 1985, at A13, col. 1; id., Dec. 10, 1985, at A4, col. 3.

The criterion of universality does not dennand unanimity, $c f$. U.S. Filartiga Memorandum, supra note 175, at 596 (discussing "the near-unanimity required for the adoption of a rule into customary international law"); but cf. Schneebaum, supra note 194, at 301 ("Lack of unanimity or universality will normally defeat this metamorphosis [of a custom into a binding legal norm], uuless it can be explained away."), but it is not clear how much less than unanimity a court should accept. Nor is it clear how a court should treat a single state which deliberately derogates from a human rights norm otherwise universally recognized. The Filartiga court was spared this inquiry because no state asserts the right to practice official torture, and very many condemn it. See Filartiga, 630 F.2d at 884 \& nn.12-14. Moreover, Judge Kaufman found that the law of Paraguay accorded with the international prohibition of official torture. Id. at 889.

213. See U.S. Filartiga Memorandum, supra note 175, at 589; Schneebaum, supra note 194, at 302. Blun and Steinhardt affirm the necessity of specific articulation of the prohibited conduct, but 
to their scope and content can be reached. ${ }^{214}$ Finally, rights must be expressed in obligatory terms. The courts must distinguish aspirational primciples such as the right to "tlie enjoyment of tlie higliest attainable standard of physical and mental health"215 from obligatory rules such as the outright prohibition of official torture. ${ }^{216}$ Only the latter, whicli call for immediate implementation and realization, create legally binding rules capable of supporting a claim under section $1350 . .^{217}$ In sum, "before entertaining a suit alleging a violation of human riglits, a court must first conclude that there is a consensus in the international commumity that the right is protected and that there is a widely shared understanding of the scope of this protection."218

International consensus is extremely important, for such consensus creates the customary rule in the first place. ${ }^{219}$ Moreover, the consensus

add that it must also be identifiable as a tort committed by individuals. Blum \& Steinhardt, supra note 12 , at 88 .

214. Cf. Restatement (REvised) OF THE Foreign Relations LAW OF THE UNited STATEs $\$ 702$ comment a (Tent. Draft No. 6, 1985) (human rights are part of customary law if their status as custom is generally accepted and there is general agreement on their scope and content).

215. See International Covenant on Economic, Social and Cultural Rights, supra note 26, art. 12 , at 51 .

216. See International Covenant on Civil and Political Rights, supra note 27, art. 7, at 53 ("No one sliall be subjected to torture or to cruel, imliuman or degrading treatment or punishment."); see also Declaration on the Protection of All Persons from Being Subjected to Torture and Other Cruel, Inhuman or Degrading Treatment or Punishment, G.A. Res. 3452, 30 U.N. GAOR Supp. (No. 34) art. 3, at 91, U.N. Doc. A/10034 (1975) ("No State may permit or tolerate torture or other cruel, inhuman or degrading treatment or punishment."); Filartiga, 630 F.2d at 884 (citing authority for proposition that torture is prohibited by constitutions of more than 55 nations).

217. See U.S. Filartiga Memorandum, supra note 175, at 597; Blum \& Steinhardt, supra note 12, at $88-89$.

218. U.S. Filartiga Memorandum, supra note 175 , at 604 . These criteria are similar to the factors examined by courts in determining whether a treaty is self-executing. Onc commentator has proposed the same general test to determine the domestic enforceability of international rights under both treaty and custom. According to Schneebaum, the proper analysis for treaty rights is to ask whether the treaty creates a "primary right," that is, an individual right to demand, or to be free from, certain conduct, whetler public or private. In answering this question, courts may examine: what the treaty actually says; what obligations the treaty imposes; whether the treaty creates a "protected class" of individuals; and whether subsequent events have materially altered the content of the treaty obligations. Sclinecbaum, supra note 194, at 293-99.

The same basic analysis would apply to customary norms, but with the additional threshold requirement that the norm in fact exist. Schneebaum concludes that:

Customary international law shares entirely with treaty law the dignity of forming a part of the law of the United States. Where each is of sufficient precision and of proper content to acknowledge or to generate individual rights, it can stand, without more, as the basis of a claim justiciable in United States courts. It is unnecessary that the existence of a private remedy be somewhere expressly provided for customary law to be enforceable, just as it has never been required that a treaty, to be self-executing, expressly so state. Id. at 307 (footnote omitted).

219. It should be evident from the character of international law that the requisite consensus concerns the nature of the substantive riglit, not remedies for its violations. See Schneebaum, supra note 194 at 306 ("Just as a treaty need not expressly provide for private enforcement to be the basis for a claim of riglits, there need be no specific consensus as to remedies for violations of customary law."). But see Case Coininent, Torture as a Tort, supra note 81, at 357 ("[T]o interpret 
evinces the various states' willingness to be bound by a rule. A court's adjudication of a section 1350 claim for a violation of the law of nations therefore depends on the international consensus for its legitimacy. Judge Kaufman demonstrated sensitivity to this principle when he wrote: "the requirement that a rule command the 'general assent of civilized nations' to become binding upon them all is a stringent one. Were this not so, the courts of one nation might feel free to mipose idiosyncratic legal rules upon others, $i m$ the name of applying international law."220 In fact, the list of fundamental human rights currently satisfying the jurisdictional requirements suggested above is short. Some argue that only four international torts qualify: official torture, genocide, slavery, and summary execution. ${ }^{221}$ Others argue for a somewhat longer list. ${ }^{222}$ The list will no doubt grow, and any newly recognized fundamental human rights sliould support claims under section 1350, provided that those riglits satisfy the criteria which ensure that they are capable of judicial enforcement im domestic courts.

The incorporation approach to the interpretation of section 1350 ehicits possible objections. It necessarily imposes on Umited States district courts the "awesome duty"223 of discovering the substantive rules of liability under mternational law. It also calls to mind the cautions of the Sabbatino Court regarding judicial competence and sensitive areas of international law. Perhaps the most serious concern is that this new rule may lave no limiting principle and will flood the federal court system with imternational law claims.

The standards governing cognizance of a fundamental human riglit under section 1350 suffice to meet some of these objections. Judge Kaufman recognized that the necessary consensus underlying the umiversality requirement imposes a strict limiting principle on the scope of section 1350 actions. $^{224}$ Because the plaintiff must satisfy the court that consen-

international human rights law to create a federal private right of action overstates the level of agreement among nations on remedies for human rights violations.").

220. Filartiga v. Peña-Irala, 630 F.2d 876, 881 (2d Cir. 1980) (quoting The Paquete Habana, 175 U.S. 677,694 (1900)).

221. See Blum \& Steinhardt, supra note 12, at 90; Note, supra note 12, at 957-58.

222. See Restatement (REvised) of the Foreign Relations LAW of THE UNITED STATES $\$ 702$ (Tent. Draft No. 6, 1985) (listing seven customary international law violations by states: genocide; slavery; murder or causing the disappearance of individuals; torture or other cruel, inhuman or degrading treatment or punishment; prolonged arbitrary detention; systematic racial discrimination; cousistent patterns of gross violations of internationally recognized human rights). The Restatement list apphies only to conduct which is practiced, encouraged or condoned by a state "as a matter of state policy." Id.; see infra note 265. Even if applied to individuals, not all of these customary international law violations will qualify as "international torts" under the three criteria proposed in this Comment for purposes of $\S 1350$ litigation.

223. Tel-Oren v. Libyan Arab Republic, 726 F.2d 774, 781 (Edwards, J., concurring) (D.C. Cir. 1984), cert. denied, 105 S. Ct. 1354 (1985).

224. See supra text accompanying note 220 . It has been suggested that the Tel-Oren opmions 
sus exists regarding the protection of the right claimed, and inust demonstrate the scope of that protection, district courts should be able to negate Sabbatino's concerns about justiciability and political sensitivity. The requirenents of universality and specificity will nean that district courts are not sitting in judgment on the human rights records of other states; rather, they will be applying ascertainable, objective standards to defendants' conduct. For this reason, too, the difficulties in ascertaining the relevant standard of hability should fall short of "awesone." Moreover, courts will not be simply implenienting their own policy views; they will be bound by the delineations of human rights expressed in the various sources of international law. ${ }^{225}$

When adjudication of section 1350 claims requires district courts to venture into unfamiliar areas of international law, it is both appropriate and beneficial to national interests that they do so, despite the expenditure of judicial resources entailed. The Supreme Court long has acknowledged that United States courts have a duty to administer international law "as often as questions of right depending upon it are duly presented for their determination." ${ }^{\text {226 }}$ In addition, the United States has a right to contribute to the developnent of niternational law, which will continue with or without the participation of our courts.

\section{Cause of Action: Second Definition}

The preceding section explored criteria for fundamental human rights which ensure that the rights are capable of judicial enforceinent under section 1350. This section proposes that fundaniental human rights imply a private right of action im individuals. In other words, suits to enforce fundamental human rights satisfy the inore recent ineaning of cause of action derived by Judge Bork from Davis v. Passman. ${ }^{227}$ Individuals suing to enforce those rights should be deemed menibers of the class of hitigants who may properly invoke the power of the courts. ${ }^{228}$

were all reactions to a perceived lack of limitations on the scope of the Filartiga opinion. See Note, supra note 12, at 947 . Such reactions do an injustice to the subtlety and far-sightedness of Judge Kaufman's opinion.

225. International conventions and declarations containing precise definitions of proseribed conduct are especially important in this regard. Cf. Filartiga, 630 F.2d at $882-83$ (noting significance of Declaration on the Protection of All Persons from Being Subjected to Torture and Other Cruel, Inhuman or Degrading Treatment or Punishment, G.A. Res. 3452, 30 U.N. GAOR Supp. (No. 34) at 91, U.N. Doc. A/10034 (1975)).

226. The Paquete Habana, 175 U.S. 677, 700 (1900); see also RESTATEMENT (REviSED) OF THE Foreign Relations LAW OF THE UNITEd States $§ 702$ comment c (Tent. Draft No. 6, 1985) ("The customary law of human rights is part of the law of the United States to be applied as such by State as well as federal courts.").

227. 442 U.S. 228 (1979).

228. See supra notes 181-82 and accompanying text. Judge Bork's cause of action is reminiscent of the "zone of interests" test for standing articulated in Association of Data Processing Service Organizations, Inc. v. Camp, 397 U.S. 150, 153 (1970). For purposes of this Comment it is 
The intensely personal, individual, and fundamental character of such human rights makes them particularly appropriate for individual enforcement. Courts im other countries have already determined that the international law of human rights endows individuals with a private right of enforcement in certain circumstances. ${ }^{229}$ There are compelling reasons why Umited States courts should reach the same conclusion.

For the individual whose human rights have been violated existing remedies are few. States have recognized the obligation to accord all mdividuals a set of minimum, fundamental human rights. One state's deprivation of these rights violates customary imternational law and gives any other state the right to sue for their vindication in the appropriate mternational or regional forum. ${ }^{230}$ But these judicial remedies belong entirely to the states. Individuals may not bring suit before the International Court of Justice ${ }^{231}$ or before any regional tribunal, sucli as the European Court of Human Riglits. ${ }^{232}$ Individuals are currently restricted to the petition process. For instance, they can submit a petition to the Umited Nations Commission on Human Rights througli the Sub-Commission on Prevention of Discrimination and Protection of

immaterial whether the issue is framed as one of cause of action or of standing. The present discussion of Judge Bork's cause of action assumes plaintiffs who are either themselves the victims of the alleged human rights violations or the survivors of those victims. Granted this assumption, the arguments offered here to demonstrate that alien plaintiffs have a cause of action within the second definition can as validly be apphed to demonstrate that they have standing to sue. Aliens with human rights claims satisfying the proposed jurisdictional requirements of $\S 1350$ will -readily establish "injury in fact" falling within the "zone of interest" protected by the relevant international legal norm.

229. See U.S. Filartiga Memorandum, supra note 175, at 602-03 \& n.44 (citing cases from the Constitutional Court of Germany, the Supreme Court of the Philippines, and the Court of First Instance of Courtrai (Belgium)).

230. See Restatement (Revised) of the Foreign Relations LaW of the UNited STATES $\S 703$ (Tent. Draft No. 6, 1985). In this regard the Restatement reflects the statist notion that offenses to individuals are really offenses to their sovereigns. It is increasingly accepted that both the U.N. Charter (as interpreted by the UDHR) and customary international law create obligations binding on states. See id. $\S 701$ comment d \& reporters' note 4. Customary human rights norms bind all states equally. $I d$. reporters' note 3 . This Comment argues, however, that in the case of a select set of judicially cognizable human rights, this legal obligation extends not merely to other states, but to the individuals themselves.

231. See Statute of the International Court of Justice, art. 38, para. 1 ("Only states may be parties before the Court."), appended to U.N. CHARTER.

232. The European Court of Human Rights was established, in conjunction with the European Commission on Human Rights, by agreement of the Council of Europe under the Convention for the Protection of Hunian Rights and Fundamental Freedoms, which came into force in 1953. The Court operates with two systems of jurisdiction, one compulsory and one optional. Under the compulsory system, the Court may hear and decide charges alleging breach of the Convention, but only where both of the states involved have accepted its jurisdiction. Under the optional system, individuals or groups of individuals may petition the Commission on Human Rights without need for any state's intervention on their behalf. If, however, the Cominission finds their petition prima facie admissible for adjudieation by the Court, the individuals inay not take the petition before the Court themselves, but must have the Commission or some state present it. See J. BRIERIY, supra note 17 , at $296-98$. 
Minorities, provided they can allege a "consistent pattern of gross and rehiably attested violations of human rights and fundamental freedoms."233 Diplomatic remedies may be available in some cases, but it is unclear why rights acknowledged to be "fundamental" must depend for their vimdication on the diplomatic process, ${ }^{234}$ which is ponderous, unrehable, and perhaps ineffective. When plaintiffs have exhausted domestic remedies, as was the case with the Filartigas, ${ }^{235}$ a suit in the courts of some other state may be their only effective means of redressing human rights violations.

The international legal system's failure to provide imdividuals with a judicial forum does not mean that domestic courts cannot or should not be accessible to mdividuals seeking to enforce their fundamental human rights. While states have discretion as to whether they will allow private enforcement for violations of imternational law, ${ }^{236}$ they also have a legitimate interest in the orderly resolution of disputes between individuals within their territory, regardless of the individuals' nationality. Further, there is no legal bar to making United States courts available to aliens suing to vindicate hunıan rights recognized under custonıary international law.

The more obvious objection to allowing individuals to sue in another state's courts is that it might violate principles of conity. That is, it might offend a state's sovereign imdependence to adjudicate treatment of its own citizens in another state's courts. But the international law of human rights "contemplates external scrutiny of such acts."237 The state has already subjected its sovereignty to restraints by acknowledging the obligation to respect fundainental human rights. Possibly, this acknowledgment alone constitutes acquiescence to adjudication of the human

233. See Procedure for Dealing with Coininuirications Relating to Violations of Human Rights and Fundamental Freedoms, E.S.C. Res. 1503, 48 U.N. ESCOR Supp. (No. 1A) at 8, U.N. Doc. E/ 4832/Add.1 (1970).

234. Cf. Lillich, supra note 25 , at 245 n.64 (questioning proposition that possibility of diplomatic remedies should bar domestic courts from enforcing customary international law rights).

235. "The requirement that domestic remedies be exhausted is met if it is shown that none arc available or that it would be futile to pursue them." RESTATEMENT (REVISED) OF THE FOREIGN Relations LAW OF THE UNited States $\S 703$ comment d (Tent. Draft No. 6, 1985). Dr. Filartiga's fruitless efforts to pursue justice through the Paraguayan criminal system, see supra text accompanying note 86 , probably constitute an exhaustion of domestic remedies. See Filartiga v. Peña-Irala, 577 F. Supp. 860, 864 (E.D.N.Y. 1984) (opinion of district court on remand) ("[B]ecause, as the record estabhishes, Paraguay will not undertake to prosecute Pena for his acts, the objective of the international law making torture punishable as a crime can only be vindicated by imposing punitive damages.").

236. See Restatement (Revised) of the Foreign Relations LAW OF THE UNITED STATES $\S 703$ comment $c$ (Tent. Draft No. 6, 1985) (Although generally "individuals do not have direct international remedies against a state violating their human rights except where such remedies are provided by intemational agreement ... [w] [hether they have a reinedy for such a violation under the law of a state depends on that law.").

237. Id. $\S 469$ coininent $\mathrm{c}$. 
rights violation in any jurisdiction where the violator is found. ${ }^{238}$ At the very least, acknowledgment of the binding duty entails consent to some adjudication of the alleged breach. Adjudicating human rights violations in a domestic forum rather than an international one is a minor restraint on a state's sovereignty relative to the vast difference for the individual plaintiff, that between having a judicial forum and having no forum at all. Moreover, the doctrine of sovereign immunity will, as a general rule, prevent the sovereign states theinselves from being sued in United States courts. $^{239}$ Thus only mdividuals whose actions violate international huinan rights can ordinarily be named as defendants.

Individuals are caught im a paradoxical bind if they are demed enforcement of their fundamental human rights in the courts of other states. Simce most fundainental human rights include some requirement of "state action" im their definitions, ${ }^{240}$ these plamtiffs will probably naine goverument officials or other individuals acting under color of law. Under these circumstances it may be extremely difficult for aliens to persuade their own states to press for vindication of their rights. ${ }^{241}$ Thus, the courts of another state may represent the aliens' only chance of vindicating their rights.

If the United States truly is committed to recognizing and protecting fundamental human rights worldwide, it should acknowledge the competence of individuals to enforce these rights themselves. Allowing section 1350 suits for the violation of fundanental human rights would also further important policy goals. It would demonstrate a willingness to devote judicial resources to the process. The suggested interpretation of section 1350 wonld further the observance and enforcement of the custoinary law of imternational human rights. No less importantly, it would involve the United States judiciary in international law, and would simultaneously increase judges' familiarity with, and contribution to, the development of that law. In a world of mcreasing interdependence, the

238. Cf. Schneebaum, supra note 194, at 306 (agreement of nations that certain acts are committed in violation of the rights of victims entails "concomitant acquiescence to the jurisdiction of any court before whom the perpetrator could be brought to justice").

239. It is possible for suits to proceed against foreign states in limited circumstances. See infra note 294.

240. $C f$. Restatement (Revised) of the Foreign Relations law of the United STATES $\$ 702$ reporters' note 2 (Tent. Draft No. 6, 1985) (state policy must mandate, encourage, or condone official's commission of acts enumerated).

241. This point underscores the peculiar fiction entailed in ascertaining a state's "consent" to be bound by its acknowledged duties to all individuals. A state's consent to be bound does not ensure that the state will be eager or willing to seek adjudication of alleged breaches of these duties by individuals acting under the color of its law. To assume that an individual's human rights are protected under a system where the state most likely otherwise to have an interest in the individual's plight is in fact the state most likely to be implicated in the alleged violation is unrealistic and perhaps even dangerous to the individual. If protection of individuals' fundamental human rights is the ultimate goal, the individuals themselves are logieally the best plaintiffs. 
need for a widely understood and uniformly practiced set of legal rules can only intensify with tiıne.

The importance of judicially cognizable fundamental human rights and the peculiar status of the individual im the current international legal order deinonstrate that section 1350 actions for "international torts" satisfy the second meaning of "cause of action" employed by Judge Bork in Davis v. Passman. ${ }^{242}$ Individuals are clearly appropriate litigants before the Umited States courts in luman rights cases.

\section{Underlying Separation of Powers Concerns: The Act of State and Political Question Doctrines}

In Tel-Oren, Judge Bork voted to affirm dismissal of the action on the ground that plaintiffs had failed to demonstrate an explicit grant of a private right of enforcement. ${ }^{243}$ One impetus behind this requirement was Judge Bork's concern that huinan riglits claims caunot be reconciled with the separation of powers principles einbodied in two doctrines of judicial abstention, the act of state doctrine and the political question doctrine. $^{244} \mathrm{He}$ did not actually rely on the doctrines themselves, but rather adduced their similar rationales in support of his position. ${ }^{245}$ Judge Robb, on the other hand, argned that the Tel-Oren claims, and apparently all others like them, fell under the political question doctrine itself. ${ }^{246}$ Simce the two opimions raise similar considerations, the following discussion will first address the act of state doctrine and then the political question doctrine. It will assess the obstacles posed by each to the assumption of section 1350 jurisdiction over human rights claims.

\section{The Act of State Doctrine and Human Rights Claims}

Judge Bork identified two concerns underlymg the act of state doctrine which he felt militated strongly against entertaining actions such as that brought in Tel-Oren, at least in the absence of an expressly granted private right of enforcement. These two concerns are the potential for judicial interference in the pohtical branches' conduct of foreign affairs and the question of an issue's fitness for judicial treatinent. ${ }^{247}$ The listor-

\footnotetext{
242. 442 U.S. 228 (1979).

243. Tel-Oren v. Libyan Arab Republic, 726 F.2d 774, 808 (D.C. Cir. 1984) (Bork, J., concurring), cert. denied, 105 S. Ct. 1354 (1985).

244. Id.; see supra text accompanying notes 183-88.

245. Tel-Oren, 726 F.2d at 803 (Bork, J., concurring).

246. Id. at 823,827 (Robb, J., concurring).

247. Id. at 802-03 (Bork, J., concurring). Judge Bork argued that:

The lack of clarity in, and absence of consensus about, the legal principles invoked by appellants, together with the political context of the challenged actions and the PLO's impingement upon American foreign relations, lead to the conclusion that appellants' case is not the sort that is appropriate for federal-court adjudication, at least not without an express grant of a cause of action.
} 
ical context in which these concerns arose, however, indicates that they should not be the basis for denying section 1350 jurisdiction over human rights claims.

The act of state doctrine emerged in this country as early as the eighteenth century froin notions of respect for the independent sovereignty of nations. ${ }^{248}$ In the classic American statement of the doctrine, Chief Justice Fuller wrote:

Every sovereign State is bound to respect the independence of every other sovereign State, and the courts of one country will not sit in judgment on the acts of the government of another done within its own territory. Redress of grievances by reason of such acts must be obtained through the means open to be availed of by sovereign powers as between themselves. ${ }^{249}$

Political conceptions of sovereignty thus absolutely prohibited one state's courts from adjudicating the sovereign acts of another state committed in that state's territory.

Beginning in 1964, the Supreine Court reexamined the doctrine in a series of cases arising from Cuban expropriations of American assets. In Banco Nacional de Cuba v. Sabbatino ${ }^{250}$ the Court held that the act of state doctrine apphies even to violations of international law. Justice Harlan, however, explained that neither the inherent nature of sovereign authority nor any principle of international law compels adherence to the doctrine. Rather, the doctrine rests upon "constitutional underpinnings" governing the proper distribution of power among the branches of government. ${ }^{251}$ To ensure the proper distribution of power im matters affecting foreign relations, Justice Harlan set forth a test which balanced three considerations: the degree of codification or consensus regarding the applicable international legal principle; the significance of the issues for the nation's foreign relations; and the status of the government whose act is under question..$^{252} \mathrm{He}$ wrote:

It should be apparent that the greater the degree of codification or consensus concerning a particular area of international law, the more appropriate it is for the judiciary to render decisions regarding it, since the courts can then focus on the application of an agreed principle to circunstances of fact rather than on the sensitive task of establishing a principle not inconsistent with the national interest or with international justice. It

\footnotetext{
Id. at 808. reporters' note 2 (Tent. Draft No. 4, 1983).

249. Underhill v. Hernandez, 168 U.S. 250, 252 (1897).

250. 376 U.S. 398 (1964).

251. Id. at 423.

252. Id. at 428.
}

248. For a discussion of the doctrine's early history, see Banco Nacional de Cuba v. Sabbatino, 376 U.S. 398, 416-18 (1964). For a summary of the later development of the doctrine, see

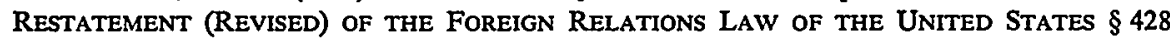


is also evident that some aspects of international law touch much more sharply on national nerves than do others; the less important the implications of an issue are for our foreign relations, the weaker the justification for exclusivity in the political branches. ${ }^{253}$

Justice Harlan stressed that the test was intended to be flexible, ${ }^{254}$ and that "[t]his decision in no way intimates that the courts of this country are broadly foreclosed from considering questions of international law."255

Applying the new test, the Court found a clear lack of international consensus regarding expropriations. ${ }^{256}$ Moreover, the Court determined that the executive branch would be better able than the courts to protect the rights of Uinited States citizens injured by expropriations. The courts could have only "occasional" impact on expropriations in violation of international law, since the courts' ability to redress violations would depend entirely on the "fortuitous circumstance of the property in question being brought into this country."257 These "pieceineal dispositions" might seriously hinder executive branch negotiations for redress. ${ }^{258}$ The

253. Id.

254. Id.

255. Id. at 430 n.34.

256. Justice Harlan stated that " $[t]$ here are few if any issues in international law today on which opinion seems to be so divided as the limitations on a state's power to expropriate the property of aliens." Id. at 428 (footnote omitted).

257. Id. at 431. The Sabbatino Court cautioned that this dependence on the fortuity of the property's presence in the United States could produce a "patchwork approach toward the formulation of an acceptable body of law." Id. at 434. Ironically, concern with thc "patchwork approacl"' threatened by conflicting state decisions may have contributed to Congress's decision to grant jurisdiction to federal district courts under $\$ 1350$. See Note, A Legal Lohengrin: Federal Jurisdiction Under the Alien Tort Claims Act of 1789, 14 U.S.F.L. REv. 105, 128-29 (1979). But the two types of "patchwork" are distinguishable. One concerns the capacity of the executive and the judiciary to provide consistent relief, while the other has to do with the consistency of decisional law in federal and state courts.

258. Sabbatino, 376 U.S. at 432 . The Sabbatino Court stressed the relatively greater efficacy of the executive in obtaining relief for United States citizens alleging illegal expropriation of their property. The executive might, through negotiations, achieve far more than case-by-case adjudication in United States courts. This was particularly so since, as the Court explained, the act of state doctrine would allow adjudication only when the disputed property was present in the Umited States (and so outside the territorial jurisdiction of the expropriating nation). See supra note 257 and accompanying text. On the other hand, the framers of the First Judiciary Act were concerned with the potential patchwork of decisions that might arise if the common law courts of various states entertained claims which were brought by aliens and iniplieated international relations.

The latter concern would have been best met by requiring aliens to choose federal courts over state courts for their $\S 1350$ claims. The framers, however, did not go so far. See supra note 43 and aceompanying text. Federal jurisdiction over $\S 1350$ suits rests in part on the "fortuity" of the plaintiff's choice of forum. (The further "fortuitous circumstance" on which depends the court's in personam jurisdiction-defendant's presence in the United States and within the jurisdictional reach of the court-affects federal and state courts equally and so favors neither.) Thus, in the federalstate context, the "patchwork" argument favors federal court adjudication. See Note, supra note 257, at 129. This conceru of the framers has lost much of its force since Sabbatino held that the 
Court therefore concluded that such cases were better left to the pohitical branches.

In two succeeding cases the Court reaffirmed the basic outlines of the act of state doctrine but debate continued over its underlying rationale. First National City Bank v. Banco Nacional de Cuba ${ }^{259}$ involved a conversion claim by Cuba's official national bank regarding the proceeds froin a sale of collateral placed with an American bank. The American bank counterclaimed, seeking to apply the contested proceeds toward the value of its branches in Cuba, which the Cuban government had expropriated. Five Justices, in three separate opinions, found that the act of state doctrine did not preclude a counterclain where the executive had suggested that the doctrine not be applied, where no showing was made that adjudication would interfere with the conduct of foreign relations, and where the counterclain was asserted as a set-off not exceeding the value of the plaintiff's claim. ${ }^{260}$ Justice Relinquist traced the doctrine's origin to principles of coinity. ${ }^{261}$

Four years later, in Alfred Dunhill of London, Inc. v. Republic of $C u b a,{ }^{262}$ the Court, in a plurahity opinion, specified that the doctrine apphies only to the public and governmental acts of a state. ${ }^{263}$ Justice White's plurality opinion stressed the purpose of avoiding embarrassment of the executive branch im the conduct of foreign relations. ${ }^{264}$

Commentators have questioned the act of state doctrine's applicability to claims based on violations of fundamental human riglits on the ground that the unratified conduct of a foreign official probably cannot be considered a governmental act under the Dunhill definition. ${ }^{265}$ More

interpretation of international law is a federal question. See supra notes $43-45$ and accompanying text.

259. 406 U.S. 759 (1972).

260. For a summary of the rationales in First Nat'l City Bank, see infra note 281.

261. First Nat'l City Bank, 406 U.S. at 762 (plurality opinion). Comity has been defined as "the recognition which one nation allows within its territory to the legislative, executive or judicial acts of another nation, having due regard both to international duty and convenience, and to the rights of its own citizens or of other persons who are under the protection of its laws." Hilton v. Guyot, 159 U.S. 113, 164 (1895).

262. 425 U.S. 682 (1976).

263. Id. at 695 (White, J., plurality opinion). Joining Justice White were Chief Justice Burger and Justices Powell and Rehnquist. Justice Stevens joined that portion of the opmion which concluded that respondents had failed to carry their burden of establishing the act of state defense. He declined to join that portion of the opinion which distinguished public and governmental acts fronı private and coinunercial acts for purposes of the act of state doctrine. Id. at 715 (Stevens, J., concurring).

264. Id. at 697. This purpose recalls the sixth of the Baker $v$. Carr elenients of the political question, "the potentiality of embarrassment froin multifarious pronouncenients by various departinents on one question." 369 U.S. 186, 217 (1962); see passage quoted supra note 132.

265. See Blum \& Steinhardt, supra note 12 , at 110 . This point was originally made by Judge Kaufman. See Filartiga v. Peña-1rala, 630 F.2d 876, 889-90 (2d Cir. 1980); see also Lillich, supra note 25, at $247 \mathrm{n.82}$ (arguing froin Filartiga dictum that the unratified conduct of a public official 
fundamentally, section 1350's jurisdictional requirement of consensus regardimg a violation of the law of nations largely obviates the need to decline review under the three-factor Sabbatino test. ${ }^{266}$ The jurisdictional requirements outlined above, particularly umiversality and specificity, will provide that "degree of codification or consensus". necessary to ensure that the court is applyimg an "agreed principle to circumstances of fact" rather than embarking on "the sensitive task of estabhishing a principle not inconsistent with the national mterest or with international justice."267

The history of the Sabbatino rule underscores this view's correctness. On the heels of Sabbatino, Congress passed the Hickenlooper Amendment, ${ }^{268}$ which overruled Sabbatino as to expropriations allegedly in violation of mternational law. ${ }^{269}$ This amendment compels United States courts im such circumstances to make determinations on the merits im order to give effect to international legal primciples. ${ }^{270}$ Congress obvi-

does not constitute an act of state); Schneebaum, International Law as Guarantor, supra note 83, at 69 ("To be an 'act of state,' an act must at the very least be endorsed, underwritten, or embraced by a sovereign as its own.").

Requiring that the act be "official" but denying that it qualifies for the act of state defense is only an apparent paradox. Not all official acts are acts of state. The distinction can perhaps be usefully couched as the difference between "action under color of state law" and "governmental action." It is the former that an international tort currently requires; it is the latter that the aet of state defense immunizes from judicial review. Thus, a police chief who tortures prisoners in his custody fulfills the requirement that his action be "official" simply by his status and the circumstances of the act-even though his action may be wholly unratified by his government or proscribed by its constitution or criminal statutes. On the other hand, a police chief who follows an express governmental policy of torturing prisoners, thougli possibly not relieved of individual responsibility under Nuremberg principles, may be able to plead an act of state defense (provided his nation is willing to claim it for him). See, e.g., Declaration on the Protection of All Persons from Being Subjected to Torture and Other Cruel, Inhuman or Degrading Treatment or Punishment, G.A. Res. 3452, 30 U.N. GAOR Supp. (No. 34) at 91, U.N. Doc. A/10034 (1975) (torture defined as "any act by whicl severe pain and suffering, whether physical or mental, is intentionally inflicted by or at the imstigation of a public official"); RESTATEMENT (REVISED) OF THE FOREIGN Relations LAw OF THE UNITED STATES $\S 702$ (Tent. Draft No. 6, 1985) ("A state violates international law if, as a matter of state policy, it practices, encourages or condones [various acts]."). Thus, a plaintiff can sue the defendant who has acted "under color of state law" but not in execution of an "act of state." For suggestions of an automatic exception to the act of state doctrine for human rights violations, see infra note 278. For a discussion of the circumstances in which a plaintiff might attempt to sue the foreign nation itself, see infra note 294.

266. See Blum \& Stemhardt, supra note 12, at 108-09. This point is also stressed in the U.S. Filartiga Memorandum, supra note 175, at 604-05. The three-factor Sabbatino test is set forth supra text accompanying note 252 .

267. See Sabbatino, 376 U.S. at 428 . The relevant passage is also quoted supra at text accompanying note 253 .

268. Foreign Assistance Act of 1965, Pub. L. No. 89-171, § 301(d)(2), 79 Stat. 653, 659 (codified as amended at 22 U.S.C. $\$ 2370(\mathrm{e})(2)(1982)$ ).

269. See Halberstam, Sabbatino Resurrected: The Act of State Doctrine in the Revised Restatement of U.S. Foreign Relations Law, 79 AM. J. INT'L L. 68, 69 \& nn.7-8 (1985).

270. See Restatement (Revised) of the Foreign Relations LaW of the UNited STATES $\S 429$ comment b (Tent. Draft No. 4, 1983).

Similarly, under the Foreign Sovereign Immunties Act, a foreign state is not immune from 
ously intended illegally expropriated property to be recovered through the courts. The amendinent thus definitively reaffirmed the coinpetence of United States courts to adjudicate the international legal questions Sabbatino had characterized as unsettled. This legislative direction is a powerful arguinent in favor of a district court's capacity, if not duty, to adjudicate claims of hunian rights violations. ${ }^{271}$

Furthermore, the Sabbatino formulation, sharply criticized at its inception, ${ }^{272}$ has undergone steady erosion. ${ }^{273}$ As early as the Dunhill decision, four Justices supported a commercial exception to the act of state doctrime. They argued that commercial dealings constitute an area of international law characterized by broad consensus concerning apphcable rules and that a decision invalidating a foreigu act would be unlikely to touch sensitive nerves in members of the international conrmunity. ${ }^{274}$ Moreover, the doctrime's applicability has been rejected by lower courts where treaties provide inanageable standards. ${ }^{275}$ Beyond the already established exceptions to the act of state doctrime, courts have evinced reluctance to apply the doctrime uncritically. Thus, in Texas Trading \& Milling Corp. v. Federal Republic of Nigeria, ${ }^{276}$ the Second Circuit espoused a case-by-case analysis of the separation of powers concerns on which the doctrime is based. It concluded that:

adjudication of the legality of Nigeria's and Central Bank's challenged conduct does not threaten to enbarrass the executive branch in its conduct of Uinted States foreign relations, and hence does not seriously implicate the relevant policy considerations.... We are not being asked, as the Court was in Sabbatino, to judge a foreign government's conduct under ambiguous principles of international law. ${ }^{277}$

This reasoning is directly apphicable to cases involving fundamental human rights. ${ }^{278}$

United States court jurisdiction over claims to property in the United States allegedly taken in violation of international law. 28 U.S.C. § 1605(a)(3) (1982); see RESTATEMENT (REVISED) OF THE FOREIGN RELATIONS LAW OF THE UNITEd STATES $\$ 429$ comment d (Tent. Draft No. 4, 1983).

271. Otherwise, a tragic and embarrassing anomaly would be perpetuated if questions involving expropriation of property continue to be better suited to adjudication than those involving the deprivation of fundamental human rights. See infra text accompanying note 279.

272. See Halberstam, supra note 269 , at $68-69 \&$ n.5 and sources cited therein.

273. Id. at $72-73$ \& n.23.

274. Dunhill, 425 U.S. $682,695-705$ (White, J., plurality opinion).

275. See Kaiamazoo Spice Extraction Co. v. Provisional Military Gov't of Socialist Ethiopia, 729 F.2d 422, 425-28 (6th Cir. 1984); American Int'l Group, Inc. v. Islamic Republic of Iran, 493 F. Supp. 522, 525 (D.D.C. 1980), modified on other grounds, 657 F.2d 430 (D.C. Cir. 1981); cf. Ramirez de Arellano v. Weinberger, 745 F.2d 1500, 1540-41 (D.C. Cir. 1984) (en banc) (dicta stating that exception may apply), vacated on other grounds, $105 \mathrm{~S}$. Ct. 2353 (1985). But cf. Callejo v. Bancomer, S.A., 764 F.2d 1101, 1118-20 (5th Cir. 1985) (treaty exccption has been applied sparingly; held inapplicable to plaintiffs' claims).

276. 647 F.2d 300 (2d Cir. 1981), cert. denied, 454 U.S. 1148 (1982).

277. Id. at $316 \mathrm{n} .38$.

278. There is increasing support for a human rights exception to the act of state doctrine. See 
The nature of the rights concerned must also be taken into account in assessing the applicability of the doctrine's rationale. Sabbatino and its progeny made clear that the act of state doctrine rests in part on a balancing of the roles of the judiciary and the political branches im securing relief for imjuries. ${ }^{279}$ Thus in Sabbatino the Court compared the value of a single, certain adjudication in federal court with the multiple potential resolutions the executive miglit achieve through negotiations. But in the context of human riglits-which are by definition individual, personal, and basic to existence-the propriety of balancing a single litigant's claim to redress against the potential claims of a broader class of victims is dubious. In human rights cases, the defendant's alleged conduct is more likely to have produced irreparable harm; a personal injury is more traumatic than an economic injury; and the need for deterrence of similar acts by the defendant and others is accordingly greater.

Most importantly, the protection of human rights is not entrusted solely to the executive brancli. Nor should it be. While human riglits issues may actually be more sensitive than the property rights issues in Sabbatino, their importance makes the argument for a deferential balancing of the judicial and the executive roles less compelling. The inportance of human rights demands their effective enforcement. United States courts in particular already perform an unwavering role in the protection of individual and minority rights. To deny courts any ability to enforce mdividual rights recognized under customary international law would foreclose a critical avenue of redress.

The foregoing discussion reveals that the separation of powers principles embodied in the act of state doctrine do not foreclose use of section 1350 jurisdiction for human rights claims as a class. The statute's jurisdictional requirements will largely satisfy concerns about interference with foreign affairs and about institutional competence. Nonetheless, it is conceivable that an individual luman rights claim might be so politi-

Haiberstam, supra note 269 , at $87 \& \mathrm{n} .89$ (discussing attempts to place human rights exception in black letter of Restatement (Revised) of the Foreign Relations Law of the United States). The latest draft of the Restatement now states:

In general, whether a particular act of a foreign state not involving expropriation comes under the act of state doctrine depends on the extent to which adjudication of the challenge would require the U.S. court to intrude into the propriety of the acts and policies of the foreign government. A claim arising out of an alleged violation of fundamental human rights-for instance, a claim on behalf of a victim of torture or genocide-would (if otherwise sustainable) probably not be defeated by the act of state defense, since the accepted international law of human rights is both well established and contemplates external scrutiny of such acts.

RESTATEMENT (REVISED) OF THE FOREIGN RELATIONS LAW OF THE UNITED STATES $\$ 469$ comment c (Tent. Draft No. 6, 1985). See generally Discussion of Tent. Draft No. 4 of the Restatement of the Law, Foreign Relations Law of the United States, 60 A.L.I. Proc. 420, 423-30, 437-39, 447-48 (1983) (comments of American Law Institute members in support of human rights exception).

279. See supra notes 257-58 and accompanying text. 
cally sensitive as to make adjudication unwise or impossible. However, an existing procedure could be adapted to deal with such cases.

The Bernstein exception-also called "executive suggestion"allows a court to proceed in a case where the act of state doctrine could apply, upon notification from the executive branch that adjudication in the particular case will not hinder the conduct of foreign relations. ${ }^{280}$ Although there is not complete accord concerning the role of the Bernstein exception, ${ }^{281}$ it has obvious imphications for the act of state doctrine's underlymg concern about judicial interference with foreign relations. A court receiving notice from the executive that adjudication is proper can hardly be deemed to "interfere" im that branch's conduct of foreign affairs. Where the executive indicates that it sees no bar to adjudication, the court may properly proceed on the merits. ${ }^{282}$

280. The "Bernstein exception" originated in a suit brought by a Jewish plaintiff after World War II to recover property. The Second Circuit initially refused to examine the validity of acts of the former Nazi governmeut. It changed its position after the State Department issued a letter announcing the "policy of the Executive ... to relieve American courts from any restraint upon the exercise of their jurisdiction to pass upon the validity of the acts of Nazi officials." See Bernstein v. N.V. Nederlandsche-Amerikaansche Stoounvaart-Maatschappij, 173 F.2d 71 (2d Cir. 1949), amended, 210 F.2d 375 (2d Cir. 1954). For a summary of the history of the Bernstein exception, see Banco Nacional de Cuba v. Sabbatino, 376 U.S. 398, 419-20 (1964).

Blum and Steinhardt discuss this same general exception under the heading of "executive suggestions regarding justiciability." See Blum \& Steinhardt, supra note 12, at 111-12.

281. The Supreine Court has engaged in considerable debate regarding the availability of the Bernstein exceptiou. In Banco Nacional de Cuba v. Sabbatino, 376 U.S. 398, 420 (1964), a change in the position taken by the Exeeutive left the Court without need to pass on the issue. See id. at 420 . The Court, however, expressed disfavor of the principle. Id. at 436. In First Nat'l City Bank v. Banco Nacional de Cuba, 406 U.S. 759 (1972), Justices Rehnquist, Burger, and White explicitly approved the exception to the act of state doctrine as a basis for decision. $I d$. at 768 . Justices Douglas and Powell rejected the Bernstein rationale but concurred in the judginent. Justice Douglas determined that the case was governed by National City Bank v. Republic of China, 348 U.S. 356 (1955) (sovereign's clain inay be offset by counterclain or set-off). He thus would allow a set-off up to the amount of the plaintiff's claim. Id. at 772-73 (Douglas, J., concurring). Justice Powell believed that the Sabbatino holding was unnecessarily broad, and concluded that the judiciary should fulfill its duty to adjudicate cases such as First Nat'l City Bank. Id. at 774-76 (Powell, J., concurring). The dissenters rejected the Bernstein exception, id. at 776-77 (Brennan, J., dissenting), and argued that the act of state doctriue is a form of the political question doctriue, $i d$. at 787-88. In Alfred Dunhill of London, Inc. v. Repubhic of Cuba, 425 U.S. 682 (1976), the issue resurfaced. Justice Powell joined Justices White, Burger, and Rehnquist in accepting the Bernstein exception. See id. at $695-98$.

This divergence steins from the different emphasis placed on the two rationales underlying the doctrine. The Justices einphasizing the rationale of interbranch comity espouse deference to the executive's wishes, whereas those interpreting the doctrine as a form of "political question" inquiry deny that executive suggestion bears any relevance to the issue. Under the political question interpretation, no executive suggestion can affect the operation of the act of state doctrine because the issue presented is simply not cognizable in United States courts. See First Nat'l City Bank, 406 U.S. at 785-90 (Brennan, J., dissenting). However, since the issues raised by fundamental human rights claims will generally be judicially cognizable, this objection should not bar the availability of the Bernstein exception in $\$ 1350$ eases.

282. The executive does not necessarily have to express approval of adjudication for each case. General exceptions to the act of state doctrine have arisen in part from "Bernstein letters" and then 
Even $\mathrm{m}$ the meager history of section 1350 , there are examples of the executive's suggesting that adjudication of the international legal issue is appropriate. In 1907 Attorney General Charles Bonaparte indicated that the federal courts' involvement in a particular foreign relations problem was proper under the statute. ${ }^{283}$ Filartiga may also be considered such a case. The Second Circuit requested the executive's interpretation of section 1350 in light of the facts of the case, and the Departments of State and Justice filed a joint memorandum urging an interpretation which supported adjudication. ${ }^{284}$

A more difficult question arises when the executive indicates that adjudication would interfere with foreign affairs. In these cases the principle of deference to the executive in matters touching on foreign relations may collide with the judiciary's understanding of its own function. Those inclined to highlight the political character of an international human rights issue would likely give dispositive weight to the executive's

developed to embrace a presumption of adjudicability absent notification from the executive. Thus, Justice Rehnquist's First Nat'l City Bank opinion indicated that there is a presumption that adjudication of a counterclaim against a foreign sovereign suing in United States court will not interfere with the conduct of foreign affairs unless the executive notifies the court that application of the act of state doctrine is required. First Nat'l City Bank, 406 U.S. at 764, 766-67. Justice Rehnquist relied on a letter from the State Department Legal Adviser advising the Court that " $[t]$ he Department of State believes that the act of state doctrine should not be applied to bar consideration of a defendant's counterclaim or set-off agamst the Government of Cuba in this or like cases." Id. at 764 (emphasis added).

The Department of State has argued for the extension of this presumption of adjudicability. Legal Adviser Monroe Leigh wrote to the Solicitor General in 1975 concerning foreign expropriations: "In general this Department's experience provides little support for a presumption that adjudication of acts of foreign states in accordance with relevant principles of international law would embarrass the conduct of foreign policy." Letter from Legal Adviser Monroe Leigh to Solicitor General Robert H. Bork (Nov. 26, 1975), reprinted in Alfred Dunhill of London, Inc. v. Republic of Cuba, 425 U.S. 682, 710 (1976) (Appendix I).

The Leigh letter, in turn, was quoted and reaflirmed in a 1982 letter from State Department Legal Adviser Davis Robimson to the Solicitor General. The Legal Adviser sought to persuade the Sixth Circuit that the court should presume adjudicability in an expropriation case involving an applicable treaty standard, witlout the need for a Bernstein letter. Letter from Legal Adviser Davis R. Robiuson to Sohicitor General Rex E. Lee (Nov. 19, 1982), reprinted in 1 S. Riesenfeld \& G. Hauck, supra note 210, at 316-17. The Sixtl1 Circuit accepted this invitation to recognize a treaty exception to the act of state doctrine. See Kalamazoo Spice Extraction Co. v. Provisional Military Gov't of Socialist Ethiopia, 729 F.2d 422 (6th Cir. 1984).

283. 26 Op. Att'y Gen. 250 (1907). See Note, supra note 257, at 120.

284. U.S. Filartiga Memorandum, supra note 175. After discussing the jurisdictional requirements of a $\S 1350$ claim grounded on fundamental human riglits, the government stated: "When these conditions have been satisfied, there is little danger that judicial enforcement will impair our foreign policy efforts. To the contrary, a refusal to recognize a private cause of aetion in these circumstances might seriously damage the credibility of our nation's counmitment to the protection of luman rights." Id. at 604.

Given Judge Bork's separation of powers concerns, it is striking that the Tel-Oren court made no recourse to executive suggestion, neither soliciting notification from the Executive nor even mentioning the government's amicus meinorandum in Filartiga. 
pronouncement. $^{285}$ Others, however, have characterized such deference as an abdication of the judicial function, and have argued that the separation of powers does not compel automatic deference. ${ }^{286}$ The relevant considerations favoring an approach that would accord executive suggestion less than controlling authority in the human rights context are the judiciary's crucial role in the development of international $\operatorname{law}^{287}$ and the fundamental character of the human right itself. Because fundainental human rights are by definition of basic importance to the individual's stature as a human being, they make an especially strong claim on the judiciary's responsibility to provide judicial resolution of grievances brought before it.

One solution to this problein would be to adopt a variation of the procedure mandated under the Hickenlooper Amendment. ${ }^{288}$ This stat-

285. The American Law Institute may have adopted this position in the Restatement (Revised) of the Foreign Relations Law of the United States. In its discussion of the Bernstein exception the Institute reports:

It seems that if the State Department issues a letter requesting that the courts not review the validity of a particular act, such a letter will be highly persuasive if not binding. . . . If the State Department issues a letter stating that it has no objection on foreign relations grounds to adjudication of the validity of a given act of a foreign state, U.S. courts will make their own determination as to whether to apply the act of state doctrine, taking the views of the Executive Branch into account but not being bound by it.

Restatement (REvised) of THE FoREIGN Relations LAW OF THE UNITED STATES § 469 reporters' note 8 (Tent. Draft No. 6, 1985) (emphasis added).

286. Criticizing the Supreme Court's decision in Republic of Mexico v. Hoffman, 324 U.S. 30 (1945) (courts must defer to executive's determination of whether to grant or deny claims of foreign sovereign immunity), Judge Jessup pointed out that "[i]t is the normal process of international affairs to insist that a question of this character must be submitted to the courts and that the diplomatic channel should be utilized only where the courts fail to do justice." Jessup, Has the Supreme Court Abdicated One of Its Functions?, 40 AM. J. INT'L L. 168, 169 (1946); see also Halberstam, supra note 269, at 76-77. Justice Powell, though not relying on the Bernstein exception for his First Nat'l City Bank concurrence, did indicate that the Sabbatino rule was overbroad. He wrote:

I do not agree, however, that balancing the functions of the judiciary and those of the political branches compels the judiciary to eschew acting in all cases in which the underlying issue is the validity of expropriation under customary international law. Such a result would be an abdication of the judiciary's responsibility to persons who seek to resolve their grievances by the judicial process.

Nor do I think the doctrine of separation of powers dictates such an abdication. . . . Until international tribunals command a wider constituency, the courts of various countries afford the best means for the development of a respected body of international law.

First Nat'l City Bank v. Banco Nacional de Cuba, 406 U.S. 773, 774-75 (1972) (Powell, J., concurring). Justice Powell subsequently accepted the Bernstein exception in Alfred Dunhill of London, Inc. v. Republic of Cuba, 425 U.S. 682 (1976). See supra note 281.

More recently, the Sccond Circuit has stated that the executive's suggestions regarding the doctrine's applicability should not control the court's decision. See Allied Bank Int'l v. Banco Credito Agricola de Cartago, 757 F.2d 516, $521 \mathrm{n} .2$ (2d Cir.) ("Whether to invoke the act of state doctrine is ultinately and always a judicial question."), cert. dismissed, $106 \mathrm{~S}$. Ct. 30 (1985).

287. See Halberstam, supra note 269, at 79-82 (view that domestic courts constitute major source for interpretation, application and development of international law); see also infra notes 31112 and accompanying text.

288. 22 U.S.C. $\$ 2370($ e)(2) (1982). See supra note 270 and accompanying text. 
ute reverses the presumption of interference with foreign relations. It requires that a court proceed to adjudication on the merits in the absence of communication froin the executive. Notification from the President that U.S. foreign policy interests require application of the act of state doctrine is binding. ${ }^{289}$ The advantage of a presuniption of adjudicability in the human rights context is that it would ehmmate the judiciary's need to interpret inconsistent executive expressions ${ }^{290}$ and would allow the courts to take account of legislative suggestions regarding adjudication of hunian rights claims. ${ }^{291}$ The courts should not, however, give executive notification the bimding effect it receives under the Hickenlooper Amendinent. For the reasons noted above, and because human rights cases lay a stronger claim to adjudication than do expropriation claims, ${ }^{292}$ courts should accord the executive's advice highly persuasive, rather than binding, authority. ${ }^{293}$

In sum, section 1350 cases grounded on abuses of judicially cognizable human rights are unlikely to interfere with the pohtical branches' conduct of foreign affairs, and there are readily adaptable procedures for dealing with special cases on an mdividual basis. Thus, the concerns Judge Bork raised under the rubric of the act of state doctrine ${ }^{294}$ can be

289. See Restatement (Revised) of the Foreign Relations LaW of the United STATES $\S 470$ comment $\mathrm{f}$ (Tent. Draft No. 6, 1985).

290. Thus, a court would not be called upon to reconcile conflicts, from administration to administration, in executive actions and statements regarding the nation's obligation to uphold human rights under international law.

291. Judge Kaufman, for instance, relied in part on the "express foreign policy of our own government" for the recognition of the principle that individuals have fundamental rights vis-a-vis their own governments under international law. As evidence of United States foreign policy, he cited two statutes: 22 U.S.C. § 2304(a)(2) ("Except under circumstances specified in this section, no security assistance may be provided to any country the government of which engages in a consistent pattern of gross violations of internationally recognized human rights."); 22 U.S.C. § 2151(a) ("The Congress finds that fundamental political, economic, and technological changes have resulted in the interdependenee of nations. The Congress declares that the individual liberties, economic prosperity, and security of the people of the United States are best sustained and enhanced in a community of nations which respect individual civil and economic riglits and freedoms ...."). See Filartiga v. Peña-Irala, 630 F.2d 876, 884-85 \& n.17 (2d Cir. 1980).

292. See supra text aecompanying note 279 .

293. Blum and Steinhardt suggest treating executive suggestions as one of several factors in the court's total calculus for determining whether abstention is required. They argue that:

to the extent that the act of state doctrine is primarily an instrument for preserving the separation of powers and thereby mininizing judicial disruption of international comity, it sliould not be used to preclude suits like Filartiga, except upon the express contrary suggestion by the executive branch. Even then, consistent with earlier decisions, such a suggestion should not be given controlling weight, but should be accorded serious consideration along with the status of the prohibition in interuational law, and the type of authorization given the official by lis state.

Blun \& Steinhardt, supra note 12 , at 112 .

294. The act of state doctrine must be distinguished from sovereign immunity, an issue that was not raised squarely by either Filartiga or Tel-Oren. But see supra note 114 (Tel-Oren plaintiffs' claim against Libya perliaps barred by sovereign immunity). The applicability of foreign sovereign immumity to $\S 1350$ actions based on luman rights violations has not been conclusively decided. 
alleviated. His concerns under the rubric of the political question doctrine, which are duphicated in Judge Robb's opinion, are addressed in the following section.

\section{Political Question Objections}

For Judge Bork the "politically sensitive nature" of the controversy over the content of relevant international legal principles, and the "political context" of the challenged actions, implicated the same separation of powers principles as did the act of state doctrine. ${ }^{295}$ Judge Robb, on the other hand, raised objections which fall within more conventional outlines of the "political question" doctrine itself. He believed that the case involved standards not judicially manageable, implicated questions

Suits against foreign officials would appear not to be barred under the Foreign Sovereign Immunities Act (FSIA), 28 U.S.C. $\S \S 1330,1602-1611$ (1982). The FSIA, the sole means by which foreign nations may be sued in federal or state courts, addresses suits against "foreign states" and their agencies and instrumentalities, and thus does not explicitly reach the actions of uddividual officials. Suits against foreign states can survive only if the court finds that the foreign sovereign is not entitled to immunity, either because the sovereign has explicitly or impliedly waived immumity, or because the action falls withm one of the Act's specified exceptions to immunity. 28 U.S.C. $\S \S 1330(a)$, 1605-1607 (1982). Plaintiffs suing under a self-executing international agreement will very likely succeed in demonstrating a waiver of immuuity. Cf. Frolova v. USSR, 761 F.2d 370, 376 n.9 (7th Cir. 1985) ("If an international agreement is self-executing and may therefore be the basis of an action under $\S 1604$ - that is, if it crcates rights enforceable by private litigants- then, in addition, it almost certainly waives sovereign immunity under $\S 1605(\mathrm{a})(1)$, thus providing a dual basis for district court jurisdiction."). Plaimtiffs suing to enforce judicially cognizable rights under the customary international law of human rights should also overcome foreign sovereign immunity claims. To the extent that international law contemplates individual enforcement of certain fundamental human rights, violations of those rights should effect an implicit waiver of sovereign immunity. Moreover, insofar as the act of state and foreign sovereign immunity doctrines share a foundation in international comity, The Schooner Exchange v. McFaddon, 11 U.S. (7 Cranch) 116 (1812), the argnments for a "human rights exception" to the act of state doctrine apply equally to foreign sovereign immunity.

For a recent decision addressing the availability of sovereign immunity in a $\S 1350$ action, see Von Dardel v. USSR, 623 F. Supp. 246 (D.D.C. 1985). See supra note 171. In Von Dardel the legal gnardian and the half-brother of Raoul Wallenberg sued the Soviet Union for allegedly violating Wallenberg's diplomatic immunity. The court entered a default judgment for plaintiffs. Considering the question of foreign sovereign immunity, the court found that defense unavailable on four different grounds: that the USSR deliberately failed to raise sovereign immunity as an affirmative defense, Von Dardel, 623 F. Supp. at 252-53; that the FSIA incorporated pre-existing standards of international law, which disallow immunity where the foreign state has acted in clear violation of universally recogmized principles of interuational law, id. at 253-54; that the USSR could not claim immunity for acts which violate treaties to which it and the U.S. are parties, id. at 254-55; that by explicitly agreeing to be bound by the terms of international human rights agreements, the USSR impliedly waived immunity against actions alleging their breach, id. at 255-56. The court also suggested that the FSIA should not be interpreted to repeal 28 U.S.C. $\$ 1350$. Id. at 254. But see Siderman v. Republic of Argentina, No. CV 82-1772 RMT (MCx) (C.D. Cal. Mar. 7, 1985) (order vacating default judgment and dismissing action) (since absolute immumity was the rule when $\S 1350$ was enacted, no exemption can be inferred from the statute's enactment; plaintiffs' claim of torture satisfies none of the exceptions listed in FSIA).

295. Tel-Oren v. Libyan Arab Republic, 726 F.2d 774, 808 (D.C. Cir. 1984) (Bork, J., concurring), cert. denied, 105 S. Ct. 1354 (1985). 
touching on sensitive matters of diplomacy, and lay beyond judicial competence because it involved the conduct of foreign affairs. ${ }^{296}$ Both judges indicated that their objections encompassed not merely the Tel-Oren case, but all human rights suits based on section $1350 .^{297}$

The political question objections raised in Tel-Oren have considerable intuitive appeal. Cases like Filartiga and Tel-Oren seem to come dangerously close to the line where judging leaves off and politics begins. It is important, however, to understand precisely what is at stake in locatmg the line at which abstention is mandated. Moreover, in striking a balance between the judiciary's limitations and its obhigations, it is necessary to account for certain considerations peculiar to the international legal context of section 1350 claims based on human rights violations.

Several preliminary observations are necessary. First, it has been argued that "imternational legal disputes are not as separable from politics as are domestic legal disputes."298 The political dimensions of international legal controversies are more visible, and any jurisdictional determination under section 1350 therefore is likely to be more politically charged than would be true in most domestic cases. ${ }^{299}$ On the other hand, the pohtical question doctrine is a judicially created doctrine of self-restraint. It is neither codified legislatively nor grounded in the Constitution apart from the separation of powers principles underlying that document. $^{300}$ Commentators have raised questions concerning the doctrine's limitations. $^{301}$ Thus, one 1might argue that the courts should not apply the doctrine unless there are weighty reasons for doing so. ${ }^{302}$

There are strong arguments agaimst applymg the political question doctrine to section 1350 clauns for violations of human rights satisfying the criteria of universality, specificity, and obligatory character. Analysis of the six elements of a pohtical question set forth in Baker v. Carr ${ }^{303}$ indicates that these section 1350 suits do not fall within the doctrine's purview. Perhaps most important is the question of judicially managea-

296. Id. at 823-26 (Robb, J., concurring).

297. Id. at 813 (Bork, J., concurring); id. at 827 (Robb, J., concurring).

298. First Nat'1 City Bank v. Banco Nacional de Cuba, 406 U.S. 759, 775 (1972) (Powell, J., concurring).

299. For the view that $\S 1350$ "requires a judicial assessment of the national interest in the context of current international politics," see Note, supra note 257, at 116 (footnote omitted).

300. See Baker v. Carr, 369 U.S. 186, 210-11, 217 (1962).

301. See Henkin, Is There A "Political Question" Doctrine?, 85 Yale L.J. 597, 622-23 (1976); McGowan, Congressmen in Court, 15 GA. L. REv. 241, 256-60 (1981). Judge Bork conceded that "the contours of the doctrine are murky and unsettled." Tel-Oren v. Libyan Arab Republic, 726 F.2d 774, 803 n.8 (D.C. Cir. 1984) (Bork, J., concurring), cert. denied, 105 S. Ct. 1354 (1985).

302. The circuit court in Sanchez-Espinoza went beyond the district court's political question analysis of the $\S 1350$ claims and examined both treaties and customary international law for evidence of a prohibition that would provide a private right of enforcement. See supra text accompanying notes $159-70$.

303. 369 U.S. 186, 217 (1962). See supra note 132. 
ble standards raised by Judge Robb. ${ }^{304}$ Because the jurisdictional requirements of section 1350 demand a high level of consensus and universality, district courts will only be asked to apply imternational rules concerning which there is substantial agreement. Indeed, the lack of consensus concerning an imternational tort of "terrorism" would have sufficed without more to decide Tel-Oren; the judges' excursion into pohtical question grounds was unnecessary. The qualifying criteria for section 1350 claims should operate to place within the courts' reach standards that are both discoverable and manageable. Likewise, these criteria should enable the courts to maintain their integrity as judicial arbiters and to avoid becoming political advocates of one ideology over another. Deciding human rights cases under section 1350 will not require the courts to make initial pohicy determinations unfit for judicial discretion.

Cases like Filartiga and Tel-Oren also do not mvolve issues for which there is a "textually demonstrable constitutional commitment" to a coordimate branch of government. ${ }^{305}$ The text of the Constitution does not commit enforcement of human rights to either political branch. Of course, some inight argue that these cases "touch on foreigu relations" and so lie properly $m$ the domain of the executive, which is solely entrusted with the conduct of foreign affairs. But that argument cuts far too broadly, for virtually any dispute mvolving international law can be said to "affect foreign relations." That the frainers of the Judiciary Act of 1789 granted jurisdiction to district courts over tort claims involving treaties and the law of nations mdicates that they foresaw adjudication of cases touching on foreigu relations and nonetheless granted the judiciary power to hear them. Thus, the preferable rule is for courts to accept jurisdiction where fundamental human rights are involved, in the absence of a compelling indication from the pohtical branches that the courts should exercise self-restramt.

Similarly, adjudication of section 1350 human rights claims will not be tantamount to expressimg a lack of the respect due coordinate branches of governinent. If the vindication of human rights were entrusted by the Constitution to either political branch, or if the nature of human rights were such that this enforcement necessitated pohtical solutions based on standards not judicially discoverable or manageable, then this political question element might apply. But the adjudication of judicially cognizable human rights under a statute expressly granting jurisdiction over ahien tort claims for violations of the law of nations can hardly be called an expression of disrespect for a coordmate branch of

304. See Tel-Oren v. Libyan Arab Republic, 726 F.2d 774, 823 (D.C. Cir. 1984) (Robb, J., concurring), cert. denied, $105 \mathrm{~S}$. Ct. 1354 (1985).

305. Baker, 369 U.S. at 217. 
government. It would more accurately be termed discharging the judiciary's proper functions.

The last elements of the Baker v. Carr list-unusual need for unquestioning adlierence to a political decision already made and the potential for embarrassment caused by multifarious pronouncements by various departments on a single question-go to the question of judicial interference with the functions of the executive. Accordingly, the arguments made about the act of state doctrime's concern with interbrancls comity apply here as well. Human riglits cases as a class do not suggest political question grounds that render them unfit for adjudication. The Supreme Court's admomition in Baker v. Carr that the doctrine is "one of 'political questions,' not one of 'pohtical cases" "306 is particularly apposite. When an individual case presents strong reasons for judicial abstention, a court has ample opportunity to refuse adjudication. This is especially so if, as suggested in the preceding section, the executive informs the court that foreign relations imterests require abstention.

This view emphasizes the judiciary's duty to adjudicate claims otherwise properly before it, and treats political question abstention as a special exception to the general rule of adjudication. It treats foreign relations implications as potentially controlling only when the executive or Congress claims exclusivity. This position is not new. Justices Frankfurter and Black advocated it in Republic of Mexico v. Hoffman, ${ }^{307}$ where the Supreme Court relied on the "interference" argument to decide that courts are bound by the executive's determination to grant a state's claim of sovereign immunity. Justice Frankfurter wrote:

It is my view . . that courts should not disclaim jurisdiction which otherwise belongs to them ... except when "the department of the government charged with the conduct of foreign relations," or of course Congress, explicitly asserts that the proper conduct of these relations calls for judicial abstention. Thereby responsibility for the conduct of our foreign relations will be placed where power lies. And unless constrained by the established policy of our State Department, courts will best discharge their responsibility by enforcement of the regular judicial processes. ${ }^{308}$

These arguments apply with equal force to claims for human rights violations, where "enforcement of the regnlar judicial processes" may represent plaintiffs' only chance for redress of their grievances.

306. Id.

307. 324 U.S. 30 (1945).

308. Id. at 41-42 (Frankfurter, J., concurring). Justice Frankfurter here implied the principle later incorporated in the Hickenlooper Amendment and other exceptions to the act of state doctrinc: courts in these cases may operate under a presumption of adjudicability. Where Justice Frankfurtcr suggests giving controlling weight to the executive's call for judicial abstention, this Comment argues for giving persuasive weight. See supra text accompanying notes 288-93. 
Other considerations militate against the general rule of abstention suggested by Judges Bork and Robb. The political question argument ignores the role of international law in United States courts and of United States courts in international law. Ever since The Paquete Habana $^{309}$ United States courts liave been bound to ascertain and administer international law in appropriate circumstances. Sweeping political question abstention would foreclose resort to a rich source of human rights law. ${ }^{310}$

The impact on the development of international law would be great as well. Automatic abstention on political question grounds would "eliminate a major source for the interpretation, application, and development of international law." 311 National courts play a significant role in niternational lawmaking. ${ }^{312}$ The abstention of American courts from adjudicatimg section 1350 human riglits claims on political question grounds would hinder the growth of international law in an area especially needing development. It would also deny the Umited States an opportunity to contribute to that growtl. Fimally, refusal to take jurisdiction over luman riglits claims is arguably a nonneutral act. Widespread refusal to accept jurisdiction over section 1350 lruman riglits claims nnight well send the message that American courts are unwilling to accept the legal status of international liuman riglits. ${ }^{313}$

Given the weakness of the grounds for pohtical question abstention, it is tempting to see Judge Robb's objections as a surrogate for another, unspoken concern. His real concern may be witlı a perceived lack of limitations on the scope of section 1350 suits under the Filartiga formulation. ${ }^{314}$ But even if the courts provide a remedy for every human riglits deprivation $\mathrm{n}$ iviolation of the law of nations, there will hardly be a crush

309. 175 U.S. 677 (1900).

310. For a discussion of the increasing willingness of U.S. judges to apply international legal rules or principles in their decisions, see Lillich, supra note 25. See also RESTATEMENT (REviSED) OF THE Foreign Relations LAW OF THE UNITED States $§ 701$ reporters' note 7 (Tent. Draft No. 6, 1985) (list of U.S. cases relying on international human rights standards).

311. Halberstam, supra note 269 , at 79 . Halberstam inakes this arguinent in a criticism of the act of state doctrine, but since it goes to the effects of abstention, it is equally applicable to the political question doctrine. So, too, is the following observation of Justice Powell:

Until international tribunals command a wider constituency, the courts of various countries afford the best means for the developinent of a respected body of international law. There is less hope for progress in this long-neglected area if the resolution of all disputes involving an "act of state" is relegated to political rather than judicial processes.

First Nat'l City Bank v. Banco Nacional de Cuba, 406 U.S. 759, 775 (1972) (Powell, J., concurring).

312. See Gordon, American Courts, International Law and Political Questions Which Touch Foreign Relations, 14 INT'L LAw. 297, 310 n.65.

313. See D'Amato, supra note 12, at 94. But see Oliver, Problems of Cognition, supra note 83, at $62-63$ (counseling judges to be cautious, lest they become "human rights activists" to the detrinent of the development of human rights law).

314. See Tel-Oren, 726 F.2d at 826 (Robb, J., concurring) ("[T]here is no obvious or subtle limiting principlc in sight."). 
of new litigation. The stringent jurisdictional requirements of section 1350, the need for botli plaintiff's and defendant's pliysical presence in the court's jurisdiction, and the possibility of sovereign immunity, forum non conveniens, or even act of state abstention, will screen out many claims. ${ }^{315}$ The specter of uncliecked new litigation is simply not substantial. To be sure, there will be an increase in the number of suits allowable under section 1350. But to the extent that these suits are grounded on judicially cognizable international rights, it is proper that United States courts be accessible for their adjudication.

\section{CONCLUSION}

This Comment lias argned that section 1350 inust be construed to accommodate the evolutionary character of international law. Under proper circuinstances, therefore, courts should entertain section 1350 claims for liuman rights violations.

The jurisdictional requirements of section 1350 do not include an express grant of a private cause of action. It is possible, however, to locate an implicit private right of action under international law. The international law of human rights now recognizes substantive individual riglits and contemplates imdividual enforcement of those rights. Therefore, individuals have a "cause of action" under both the traditional and more recent meanings of the terin which Judge Bork drew from Davis $v$. Passman. These human rights claims, however, inust still satisfy the criteria of universality, specificity, and obligatory character.

Neither the act of state nor the political question doctrine poses an obstacle to human rights claims satisfying these three jurisdictional requirements. Courts slould presume that such claims are adjudicable. Executive requests for exclusivity in cases with significant foreign policy implications inerit persuasive, but not controlling, weight.

The construction of section 1350 requires refining. The list of human rights qualifymg for cognizance under section 1350 likely will evolve. Courts have not conclusively determined the availability of defenses such as foruin non convemiens and sovereign immunity. Most importantly, the judicial responses to Filartiga-Tel-Oren and SanchezEspinoza-provide at best uncertain precedent. Nor have commentators resolved the debate.

The Filartiga principle, however, is essentially sound. Both the his-

315. See Note, supra note 12, at 956-65 (requirement of showing a "violation of the law of nations" as well as defendant's responsibility under international law provides sufficient limiting principle). For a discussion of the requirements of personal jurisdiction in $\S 1350$ cases, see supra note 47. See also Comment, After Tel-Oren, supra note 107, at 305.09 (doctrine of hostis humani generis limits scope of application of $\$ 1350$ ); Note, Separation of Powers, supra note 107, at 716-18 (list of limiting principles). 
torical context in which Congress passed the statute and the current state of international law demonstrate that United States district courts can accept jurisdiction of human rights claims under section 1350 . It is incumbent on the courts to acknowledge the statute's grant of jurisdiction and to develop its jurisprudence.

Andrew M. Scoble*

* B.A. 1977, University of California, Santa Cruz; third-year student, Boalt Hall School of Law, University of California, Berkeley. 
